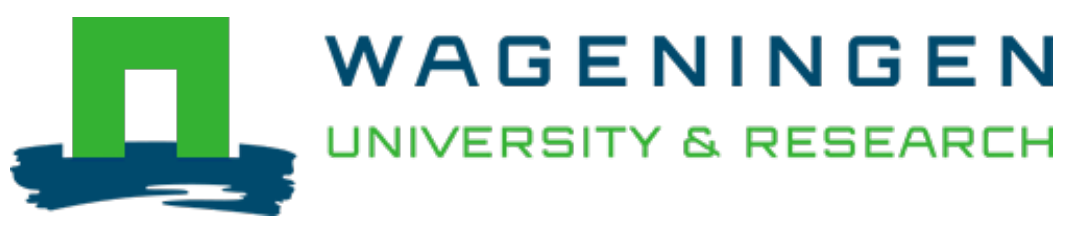

\title{
Diseases Caused by Pectobacterium and Dickeya Species Around the World
}

Plant Diseases Caused by Dickeya and Pectobacterium Species

Wolf, J.M.; Acuña, Ivette; Boer, Solke H.; Brurberg, M.B.; Cahill, Greig et al

https://doi.org/10.1007/978-3-030-61459-1_7

This article is made publicly available in the institutional repository of Wageningen University and Research, under the terms of article $25 \mathrm{fa}$ of the Dutch Copyright Act, also known as the Amendment Taverne. This has been done with explicit consent by the author.

Article $25 \mathrm{fa}$ states that the author of a short scientific work funded either wholly or partially by Dutch public funds is entitled to make that work publicly available for no consideration following a reasonable period of time after the work was first published, provided that clear reference is made to the source of the first publication of the work.

This publication is distributed under The Association of Universities in the Netherlands (VSNU) 'Article $25 \mathrm{fa}$

implementation' project. In this project research outputs of researchers employed by Dutch Universities that comply with the legal requirements of Article $25 \mathrm{fa}$ of the Dutch Copyright Act are distributed online and free of cost or other barriers in institutional repositories. Research outputs are distributed six months after their first online publication in the original published version and with proper attribution to the source of the original publication.

You are permitted to download and use the publication for personal purposes. All rights remain with the author(s) and / or copyright owner(s) of this work. Any use of the publication or parts of it other than authorised under article $25 \mathrm{fa}$ of the Dutch Copyright act is prohibited. Wageningen University \& Research and the author(s) of this publication shall not be held responsible or liable for any damages resulting from your (re)use of this publication.

For questions regarding the public availability of this article please contact openscience.library@,wur.nl 


\title{
Chapter 7 \\ Diseases Caused by Pectobacterium and Dickeya Species Around the World
}

\author{
Jan M. van der Wolf, Ivette Acuña, Solke H. De Boer, May B. Brurberg, \\ Greig Cahill, Amy O. Charkowski, Teresa Coutinho, Triona Davey, \\ Merete W. Dees, Yeshitila Degefu, Brice Dupuis, John G. Elphinstone, \\ Jiaqin Fan, Esmaeil Fazelisanagri, Thomas Fleming, Nahid Gerayeli, \\ Vladimir Gorshkov, Valérie Helias, Yves le Hingrat, Steven B. Johnson, \\ Andreas Keiser, Isabelle Kellenberger, Xiang (Sean) Li, Ewa Lojkowska, \\ Rodney Martin, Juliana Irina Perminow, Olga Petrova, \\ Agata Motyka-Pomagruk, Simeon Rossmann, Santiago Schaerer, \\ Wojciech Sledz, Ian K. Toth, Leah Tsror, Jacquie E. van der Waals, \\ Patrice de Werra, and Iris Yedidia
}

J. M. van der Wolf $(\bowtie)$

Wageningen University and Research, Business Unit Biointeractions and Plant Health, 6700 AA

Wageningen, The Netherlands

e-mail: Jan.vanderWolf@wur.nl

I. Acuña

Instituto de Investigaciones Agropecuarias, INIA, Santiago, Chile

S. H. De Boer · X. Li

CFIA Charlottetown Laboratory, Charlottetown, PE, Canada

M. B. Brurberg · M. W. Dees · J. I. Perminow · S. Rossmann

NIBIO-Norwegian Institute of Bioeconomy Research, Ås, Norway

G. Cahill

SASA, Edinburgh, Scotland, UK

A. O. Charkowski

Colorado State University, Fort Collins, USA

T. Coutinho

CMEG/FABI, University of Pretoria, Pretoria, South Africa

T. Davey

SASA, Edinburgh, UK

Y. Degefu

Luke, Oulu, Finland

B. Dupuis

Agroscope, PPP, Nyon, Switzerland

J. G. Elphinstone

Fera Science Ltd, York, UK

J. Fan

Nanjing Agricultural University, Nanjing, China 


\begin{abstract}
Soft rot Pectobacteriaceae (SRP) are ubiquitous on earth as there are records of findings from all continents where host plants are grown. This chapter describes information on soft rot diseases on these continents. For some countries, detailed information is provided by local experts on the SRP present, their economic damage, and the management strategies applied for their control. The focus of the chapter is mainly on SRP as causative agents of potato blackleg, although in specific cases details are provided on SRP in other host plants. In Europe, the SRP cause important economic losses mainly on potato, with most species described in the literature being found. In Latin America significant losses are also reported due to potato diseases caused by various Dickeya and Pectobacterium species, while in Australia and Oceania, recent outbreaks of $D$. dianthicola in potato have resulted in high economic losses. In Asia, however, SRP cause economic losses mainly in vegetable crops other than potato, while in North America SRP cause diseases on a wide range of crops (including potato and ornamental plants) in both field and storage. In Africa SRP are only known to occur in 17 of the 54 African countries but where it is known, potato is the most affected crop.
\end{abstract}

E. Fazelisanagri · N. Gerayeli

Ferdowsi University of Mashhad, Mashhad, Iran

T. Fleming

AFBI, Belfast, UK

V. Gorshkov · O. Petrova

KIBB FRC Kazan Scientific Center of RAS, Kazan, Russia

V. Helias · Y. le Hingrat

FN3PT/inov3PT, Paris, France

S. B. Johnson

University of Maine, Maine, USA

A. Keiser · P. de Werra

HAFL, BFH, Zollikofen, Switzerland

I. Kellenberger · S. Schaerer

Agroscope, Nyon, Suisse

E. Lojkowska · A. Motyka-Pomagruk · W. Sledz

University of Gdansk, Gdansk, Poland

R. Martin

DAERA, Belfast, UK

I. K. Toth

James Hutton Institute, Dundee, UK

L. Tsror

Agricultural Research Organization, Gilat, Israel

T. Coutinho $\cdot$ J. E. van der Waals

University of Pretoria, Pretoria, South Africa

I. Yedidia

Agricultural Research Organization, Volcani Center, Israel 


\subsection{Introduction}

Soft rot Pectobacteriaceae (SRP) are ubiquitous on earth as there are records on findings from all continents were host plants of SRP are grown (Table 7.1). For instance, Pectobacterium atrosepticum, P. carotovorum, Dickeya chrysanthemi, D. dianthicola and $D$. zeae are found on all continents where hosts are grown. The diversity of SRP and the economic impact of the diseases they cause in specific regions, however, are largely dependent on the diversity of agricultural and horticultural crops cultivated, the environmental conditions and the extent of trade. The trade of vegetative materials, including potato seed tubers and ornamentals, is largely responsible for the wide distribution of many of the SRP species (Toth et al. 2011). Locally, they also spread through plant remains, soil, waterways, air, aerosols, alternative hosts and/or agricultural machinery (Pérombelon and Kelman 1980). While this chapter introduces the importance of SRP in a number of continents and countries, it should be stated that we have not been able to cover all area and, therefore, other countries that have not been mentioned are not necessarily free from SRP and the diseases they cause.

Table 7.1 Presence of Dickeya and Pectobacterium species in six different (sub)continents

\begin{tabular}{|c|c|c|}
\hline Pathogen & Present in (sub)continent(s) & References \\
\hline D. aquatica & Europe & Parkinson et al. (2014) \\
\hline D. chrysanthemi & All & https://gd.eppo.int \\
\hline D. dadantii & $\begin{array}{l}\text { Africa, Asia, Europe, Latin } \\
\text { America and North America }\end{array}$ & $\begin{array}{l}\text { Soleimani-Delfan et al. (2015); Sławiak et al. (2009a, } \\
\text { b); Ngadze et al. (2010); Greiner (2019); Ogoshi et al. } \\
\text { (2019) }\end{array}$ \\
\hline D. dianthicola & All & www.cabi.org/isc/datasheet \\
\hline D. fangzhongdai & Asia, Europe & Alič et al. (2019) \\
\hline D. lacustris & Europe & Hugouvieux-Cotte-Pattat et al. (2019) \\
\hline D. oryzae & Asia, Europe, Australia & Wang et al. (2020) \\
\hline D. poaceiphila & Australia & Hugouvieux-Cotte-Pattat et al. (2020) \\
\hline D. paradisiaca & Latin America & Peckham et al. (2010) \\
\hline D. solani & Asia, Europe, Latin America & www.cabi.org \\
\hline D. undicola & Asia, Europe & Oulghazi et al. (2019b) \\
\hline D. zeae/D. oryzae & All & www.cabi.org, Wang et al. (2020) \\
\hline P. actinidae & Asia & Portier et al. (2019) \\
\hline P. aquaticum & Europe & Pédron et al. (2019) \\
\hline P. aroidearum & $\begin{array}{l}\text { Africa, Asia, Europe, Latin } \\
\text { America }\end{array}$ & $\begin{array}{l}\text { Moraes et al. (2017); Xie et al. (2018); Nabhan et al. } \\
\text { (2012a; b); Gorter (1977); Nabhan et al. (2013) }\end{array}$ \\
\hline P. atrosepticum & All & https://gd.eppo.int \\
\hline P. betavasculorum & Asia, Europe, North America & Gardan et al. (2003); Baghaee-Ravari et al. (2011) \\
\hline P. brasiliense & All & $\begin{array}{l}\text { Naas et al. (2018); Choi and Kim (2013); Duarte et al. } \\
\text { (2004); Li et al. (2015); Tesoriero (2018); Nunes Leite } \\
\text { et al. (2014) }\end{array}$ \\
\hline
\end{tabular}


Table 7.1 (continued)

\begin{tabular}{|c|c|c|}
\hline Pathogen & Present in (sub)continent(s) & References \\
\hline P. carotovorum & All & www.cabi.org/isc/datasheet \\
\hline P. fontis & Asia & Oulghazi et al. (2019a) \\
\hline P. odoriferum & $\begin{array}{l}\text { Africa, Asia, Australia, Europe, } \\
\text { Asia }\end{array}$ & Portier et al. (2019); Oskiera et al. (2017) \\
\hline P. parmentieri & North America & www.cabi.org/isc/datasheet \\
\hline P. parvum & Europe, Asia & Pasanen et al. (2020) \\
\hline P. peruviense & Europe, Latin America & Waleron et al. (2018); Faye et al. (2018) \\
\hline P. polaris & Europe, Africa & Dees et al. (2017a; b); Oulghazi et al. (2020) \\
\hline P. polonicum & Europe & Waleron et al. $(2019 \mathrm{a}, \mathrm{b})$ \\
\hline P. punjabense & Asia, Europe & $\begin{array}{l}\text { Sarfraz et al. (2018); V Helias (INRA, Rennes, } \\
\text { France), personal communication }\end{array}$ \\
\hline P. versatile & $\begin{array}{l}\text { Africa, Asia, Europe, North } \\
\text { America }\end{array}$ & Portier et al. (2019); Oulghazi et al. (2020) \\
\hline P. zantedeschia & Europe & Waleron et al. (2019a) \\
\hline
\end{tabular}

Until recently, $P$. atrosepticum was considered the primary pathogen causing blackleg and soft rot in potatoes in Europe and North America (Pérombelon and Kelman 1980; Pérombelon and Hyman 1989; Sledz et al. 2000; Pérombelon 2002; Toth et al. 2011). However, from the 1970s in Europe, D. dianthicola increased in prevalence, until the appearance of D. solani in the early 2000s (Cazelles and Schwaerzel 1992; Parkinson et al. 2009; Slawiak et al. 2009; Toth et al. 2011). Since 2004, D. solani has been isolated in many European countries including the Netherlands, Greece, Finland, France, Norway, Poland, and in Israel (Sławiak et al. 2009a, b; Tsror et al. 2009; Sarris et al. 2011; Degefu et al. 2013; van der Wolf et al. 2013; Golanowska et al. 2016; Jiang et al. 2016; Potrykus et al. 2016; Dees et al. 2017a). Under high temperature conditions, D. solani is more virulent in potato than other Dickeya species (Czajkowski et al. 2009), therefore, several countries have undertaken preventive measures to reduce its spread. For example, Scotland introduced a 'zero tolerance' policy for Dickeya spp. in potato production systems in 2010 (Toth et al. 2011). Israel, North African countries and Jamaica have listed Dickeya spp. as a quarantine pest. In the last five years in North America and Australia outbreaks of blackleg and non-emergence caused by $D$. dianthicola resulted in high economic losses in some potato producing areas. Nevertheless, Pectobacterium spp. remain important pathogens. P. atrosepticum (Tsror et al. 1999, 2009; Toth et al. 2011; Jiang et al. 2016; Potrykus et al. 2016; Ma et al. 2018; Zoledowska et al. 2018; Pérombelon 2002; Motyka et al. 2017) is still an important, if not the most important, causal agent of blackleg and aerial stem rot in potato in specific temperate regions, including the UK and North America, but is rarely found to cause disease on other crops or in other climates, suggesting a degree of host and temperature specialization (Ngadze et al. 2012; Pérombelon and Kelman 1987). The recent spread of P. parmentieri, and other species such as $P$. brasiliense, is indicative of the expanding diversity and 
distribution of soft-rotting bacteria in Europe, North America, South Africa and New Zealand.

The presence of $P$. parmentieri has been confirmed in Germany, Finland, Poland, Norway, Spain, Switzerland, the Netherlands, Pakistan, Russia, New Zealand, Canada, USA and The Republic of South Africa (Sarfraz et al. 2019; Oulghazi et al. 2019a, b; Pitman et al. 2010; De Boer et al. 2012; Dung et al. 2012; Nabhan et al. 2012a; Ngadze et al. 2010; Moleleki et al. 2013; Pasanen et al. 2013; Waleron et al. 2013; Rosenzweig et al. 2016; Suárez et al. 2017; Ge et al. 2018; Zoledowska et al. 2018). P. parmentieri strains, many of which were previously classified as $P$. carotovorum. subsp. carotovorum or $P$. wasabiae, now constitute $15 \%$ of the softrotting Pectobacterium species isolated from potato in Poland (Waleron et al. 2013; Motyka et al. 2017), 16\% in Canada (De Boer et al. 2012), and 5\% in New Zealand (Pitman et al. 2010).

P. brasiliense has caused severe losses in recent years (Duarte et al. 2004). This pathogen was first characterized from potato in Brazil and was later detected in other warm climates including Brazil, South Africa, Zimbabwe (Ngadze et al. 2012; Nabhan et al. 2012b), Syria (Nabhan et al. 2012b), and Kenya (Moleleki et al. 2013). However, it is also present in temperate climates including Canada, Germany, New Zealand, Peru, Poland, Switzerland, Japan, Russia, Algeria, Turkey and The Netherlands (Voronina et al. 2019; Naas et al. 2018; Ozturk et al. 2018; Fujimoto et al. 2017; Pitman et al. 2010; Nabhan et al. 2012a; Nunes Leite et al. 2014; de Werra et al. 2015a; Waleron et al. 2015). Strains identified as belonging to this species also caused disease on economically important plant species in USA, Japan, Korea, China, Venezuela, Colombia, Israel and New Zealand (Gillis et al. 2017; Jaramillo et al. 2017; Meng et al. 2017; Ma et al. 2007; Nabhan et al. 2012a; Panda et al. 2012; Choi and Kim 2013; Lee et al. 2014; Tsror et al., Gilat, Israel, unpublished data). P. brasiliense is now one of the most commonly isolated SRP on potato in Europe, having spread rapidly since its first appearance and has largely replaced $D$. solani in many areas (Waleron et al. 2015).

In this chapter, an inventory has been made of the SRP genera and species that are known to be present on the different continents (Table 7.1). The occurrence and importance of soft rot-like diseases of woody plants in the territory of the post-Soviet region (Russia, Belarus, Ukranin, Kazahstan and Baltic republics), which are caused by the invalidly named 'Erwinia multivora' (a possible variant of P. carotovorum) (Cherpakov 2016, 2017), are also briefly summarized. For several countries, detailed information is provided by local experts on the diversity of SRP present, on the economic damage and on the management strategies applied for disease control. The focus is mainly on causative agents of potato blackleg, although in specific cases details are provided on SRP in other host plants. In some reports on the diversity of SRP present, in particular from countries where specialized diagnostic laboratories are limited, the identification of pathogens up to species level should be considered with caution. Specifically, the indication that $P$. carotovorum has been identified as a causal organism, may mean that Pectobacterium species other than P. atrosepticum were found. In this chapter, only confirmed reports of findings are listed and not 
strains deposited in culture collections, for which it is not always clear whether they were isolated from hosts grown in those countries listed.

\subsection{Europe}

In Europe, most SRP species described in the literature have been found. In the case of D. lacustris, $D$. undicola and $P$. aquaticum that were isolated from surface water, plant hosts (assuming that they exist) are unknown. For potato, the diversity of blackleg-causing SRP species is strongly correlated with the import policy of a country. For example, in Norway and Scotland, which only allow the import of in vitro potato material, $P$. atrosepticum remains the dominant species, whereas in countries with a more open import policy a higher diversity of SRP species is found. It should be noted that a higher diversity of SRP species in plants for planting does not necessarily coincide with a higher blackleg disease incidence.

In the European Union, for seed potatoes, certification depends on field inspections whereby Grade S, SE and A seed should not exceed 0.1, 0.5 and $2 \%$ blackleg affected plants, respectively (directive 2020/177/UE). However, several member states have a more stringent tolerance. In many EU countries, including the Netherlands and France as major seed potato producers, blackleg is responsible for most of the declassifications and rejections, indicating its importance.

To prevent introduction of SRP into high grade seed, so-called 'safe haven' areas have been created in different regions in Europe in which introduction of low grade seed is prohibited, e.g. Finland (North Finland), Northern Ireland, Scotland and Northern England (UK), parts of Germany and The Azores (Portugal).

\subsubsection{Finland}

Finland is the world's northern most agricultural country. Finnish farmlands reach from the 60th latitude to north of the Arctic Circle. Potato is among the important food crops produced in Finland. The production area is estimated to be about 28,000 hectares stretching over $100 \mathrm{~km}$ wide zone along the Gulf of Bothnia, between latitudes $60^{\circ}$ and $63^{\circ} \mathrm{N}$ and longitudes $22^{\circ}$ and $25^{\circ} \mathrm{E}$. Finland is among the five countries within Europe granted High Grade (HG) status_ - "safe haven" for seed potato production.

Most of the varieties of seed potatoes cultivated in Finland are imported from The Netherlands with a limited number coming from Germany. Due to the free trade agreements and trade liberalization within the EU, and free introduction of planting materials from abroad, potato production in Finland is facing threats from introduction and establishment of potentially harmful pathogens previously unknown (Hannukkala 2011), even in the North HG areas (Degefu et al. 2013). In recent years, 
SRP have become consistent threats to potato production in Finland (Degefu 2015), and has also caused carrot spoilage in storage (Kahala et al. 2012).

Over the past three decades testing of seed for potato blackleg and soft rot in Finland has undergone significant change (Degefu et al. 2009, 2013; Harju and Kankila 1993; Hannukkala 2011). Following advances in the molecular detection and monitoring of SRP, emerging and re-emerging Dickeya and Pectobacterium spp. occurring on potato in Finland have been documented (Degefu et al. 2009, 2013; Degefu 2015; Laurila et al. 2010). Regular surveys, monitoring and characterization of blackleg outbreaks, routine detection of latent SRP species using diagnostic TaqMan and conventional PCR assays have been conducted since 2000 (Degefu et al. 2013). As a result, $P$. atrosepticum, . brasiliense, $P$. parmentieri, $P$. carotovorum and $D$. solani are consistently detected in seed tubers as well as blacklegand soft rot diseased potato plants. P. polaris, recently described as causing soft rot of potato in Norway (Dees et al. 2017b), has also been isolated from potato in Finland. However, its prevalence and pathogenicity on potato under Finnish conditions is not yet determined (Pirhonen, Helsinki, Finland, personal communication). SRP species are known to have different optimal temperature ranges for growth (du Raan et al. 2016). The high diversity of SRP species makes it likely that blackleg and soft rot can occur irrespective of the climate conditions during summer. In addition, the changing populations of SRP species, partly driven by changing climate conditions, add to the complexity of diagnosis and possibly the management of soft rot. In Finland, seed testing for SRP is not mandatory. However, most seed potato companies test their seed to avoid compensation demands from farmers in the event of blackleg and soft rot outbreaks. Recently, seed companies have adopted a zero tolerance to D. solani due to its aggressive and invasive nature. This practice has helped to minimize the problem of blackleg and soft rot caused by Dickeya spp. even during hot springs and summers, which typically favour outbreaks of blackleg and soft rot due to D. solani (Degefu 2018). Under Finnish conditions, 5 to 7 days with temperatures of $25^{\circ} \mathrm{C}$ and above are sufficient for blackleg development and spread (Degefu, Oulu, Finland, personal observation).

\subsubsection{France}

France is the world's top exporter of arable crop seeds, trading with 150 countries across five continents. France is also the second main producing and exporting country for seed potatoes (www.gnis.fr), with an annual production of 550,000 tonnes of certified seed potatoes in 2018/2019 of which 221,000 tonnes were exported to more than 70 countries (www.plantdepommedeterre.org). In 2018, the production included 470 potato varieties (data 2018).

The economic damage caused by SRP on potato is variable, but may be significant depending on weather conditions during the year. Besides potato, several vegetable crops, such as chicory and radish, have also suffered from severe soft rot epidemics in the past decades. Under favourable conditions, crop losses of chicory roots due 
to soft rot infection by $P$. carotovorum can exceed $50 \%$ and can rise to more than 90\% for Dickeya spp. (Le Hingrat et al. 2012). Surveys conducted in radish fields prompted the identification of $P$. carotovorum as the species associated with disease, which can result in the complete destruction of the rotted roots (Mériaux 2011), while stem infection is rare. Losses due to soft rot in other susceptible host plants are more sporadic, and consequently much less documented. However, SRP have also been reported on other vegetables in France (Table 7.2).

In potato, SRP cause significant damage to potato seed and ware crops, producing soft rot and blackleg diseases. Blackleg is of special concern for the seed potato sector, as it is the main criterion for field inspections and is subject to strict levels of tolerance for seed certification. Consequently, the presence of blackleg in a seed crop may result in rejection or downgrading of the crop. In France, blackleg is regularly the first or second cause for rejection of seed potato crops during field inspection (around 25 to 45\%; FN3PT annual reports 2007-2017). Between 50 and 600 hectares, which represents between 0.25 and $3.2 \%$ of the seed potato area, are rejected each year because of blackleg. The total annual value of these losses can be up to $3 \mathrm{M}$ euro. However, it is more difficult to quantify other consequences such as economic losses due to downgrading, cost of prophylactic measures, and losses in the ware and processed potato sectors.

Field surveys conducted annually in France since 2003 have shown that typical blackleg symptoms are associated with a bacterial complex that include several species (Fig. 7.1). Plant sampling and analyses have shown that besides $P$. atrosepticum, historically associated to blackleg in temperate climates, $P$. carotovorum and Dickeya spp. were systematically detected each year (Fig. 7.2). Furthermore, several species may be detected simultaneously in the same field or even plant.

Results from the surveys summarized in Fig. 7.2 shows the predominance of the genus Pectobacterium in plants with blackleg symptoms across all years tested, with the only notable exception in 2005 when warm cropping conditions were more favourable to Dickeya spp. Intensive phenotypic and molecular characterisation of $P$. carotovorum isolates collected between 2003 and 2017 from 1027 potato fields, resulted in the identification of $P$. parmentieri, $P$. brasiliense and $P$. carotovorum. Further studies, involving partial or complete sequencing of bacterial genomes, also showed the presence of the newly identified species $P$. polaris, $P$. versatile, $P$.

Table 7.2 Symptomatic vegetable and ornamental crops from which Pectobacterium and Dickeya have been isolated in France

\begin{tabular}{l|l|l}
\hline & Hosts of Pectobacterium & Hosts of Dickeya \\
\hline Vegetables and arable crops & $\begin{array}{l}\text { Tomato, Artichoke, Witloof } \\
\text { chicory, Lettuce, Celery, } \\
\text { Cauliflower, Sunflower, Leek, } \\
\text { Potato }\end{array}$ & $\begin{array}{l}\text { Tomato, Artichoke, Chicory, } \\
\text { Sunflower, Maize, Pineapple, } \\
\text { Radish, Potato }\end{array}$ \\
\hline Ornamentals & $\begin{array}{l}\text { Cyclamen, Philodendron, } \\
\text { Arum, Primrose, Hyacinth, Iris, } \\
\text { Chrysanthemum }\end{array}$ & $\begin{array}{l}\text { Carnation, Dahlia, } \\
\text { Dieffenbachia, Spurge, } \\
\text { Saintpaulia, Kalanchoe }\end{array}$ \\
\hline
\end{tabular}




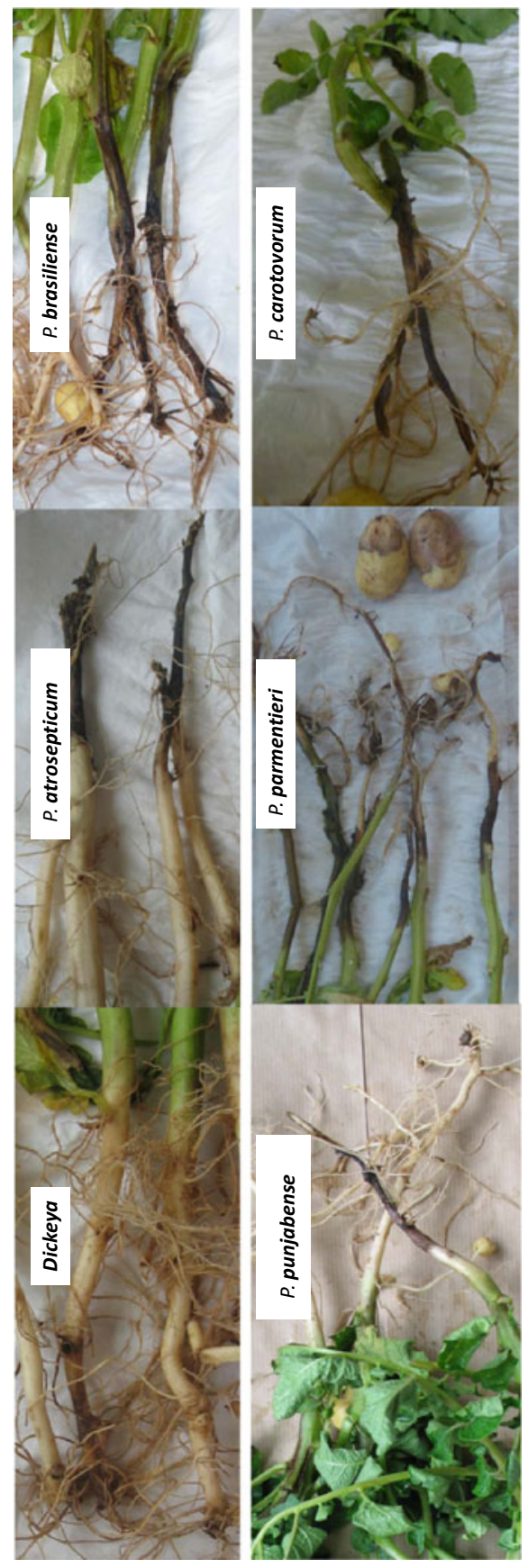

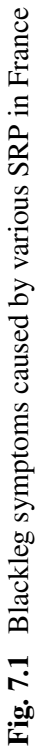




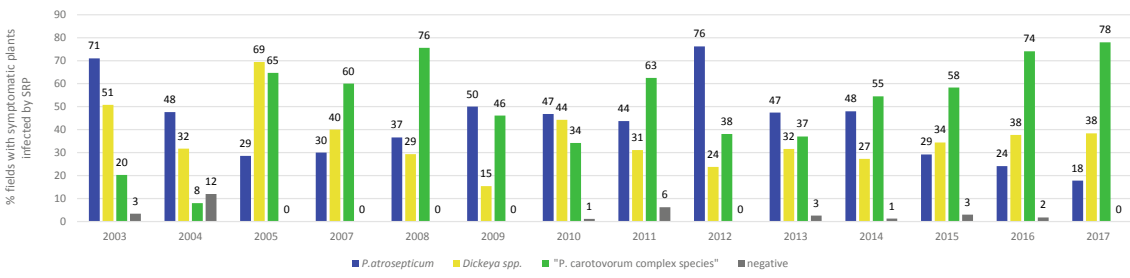

Fig. 7.2 Distribution of soft rot Pectobacteriaceae (P. atrosepticum, Dickeya spp., "P. carotovorum complex" species) in potato crops in France detected in blackleg diseased plants between 2003 and 2017

odoriferum and $P$. punjabense (Chawki et al. 2018). These newly described species were initially identified as $P$. carotovorum. In 2005, D. solani was identified for the first time where previously $D$. dianthicola was the only described blackleg causing Dickeya species. It is important to note that symptomatic plants often harbour a mix of pathogen species.

The certification of seed potatoes is currently based on visual inspection of seed crops and roguing of visibly infected plants. French tolerance levels for blackleg range from 0 (pre-basic seed, classes S and SE) $0.5 \%$ (class E) to 1\% (class A), and are more stringent than those of directive 2020/177/UE, which has tolerance levels of $0 \%$ for pre-basic, $1 \%$ for basic and $4 \%$ for certified potatoes. On tuber lots, the tolerance for dry- and soft rot is $0 \%$ for minitubers (pre-basic tissue culture, PBTC) and $0.2 \%$ for wet rots (after grading) for all other classes.

Laboratory testing by an enrichment (bio)-PCR (using generic (Y1/Y2) primers for Pectobacterium spp. and generic (ADE1/pelADE2) primers for Dickeya spp. (Czajkowski et al. 2015) is used officially for testing the initial material (i.e. the mother plants used at the beginning of the seed propagation process), in accordance with directive 2020/177/UE. Molecular methods allowing the detection and/or quantification of latent bacterial contamination of seed lots have also been developed and transferred to seed potato laboratories after validation. For this, methods have been evaluated over a 3 years period using progenies of seed lots with known initial latent infections grown in several locations (Hélias et al. 2017). Tuber testing provides useful information on latent bacterial infections. However, this alone is not sufficient to predict the occurrence and/or the severity of the disease in daughter crops since disease development is also strongly dependent upon local environmental and agronomic conditions. Therefore, to date, tuber testing has not been introduced in the certification scheme and is used only on a voluntary basis to help growers and commercial operators to reduce the risk of blackleg through a holistic health management initiative for seed potato crops. 


\subsubsection{Norway}

Norway produces its own seed potatoes and, in order to prevent introductions of new potato pathogens into the country, import of foreign seed potatoes is prohibited. Exceptions are made for breeding purposes but these small numbers of tubers need to be tested free from pathogens in their country of origin and are then initially grown under quarantine conditions in Norway. Potato blackleg and soft rot are responsible for most of the cases of rejection or downgrading performed by seed potato certification authorities. Ware potato producers can also experience big crop losses as a consequence of these diseases. In recent years, Norwegian farmers have reported major blackleg occurrences and, throughout recent seasons, multiple incidents of non-emergence due to rotting seed tubers have been reported.

In Norway, which has a temperate climate with a high level of precipitation in most years, $P$. atrosepticum is the dominant blackleg causing species, as it favours lower temperatures compared to other SRP species, while the high humidity favours all SRP species equally. $P$. carotovorum has also been isolated regularly, mainly from rotting potato tubers (Dees et al. 2017a). Nevertheless, in recent years new highly virulent SRP species have been detected. For example, in 2010 P. parmentieri was isolated for the first time in Norway in a potato plant with severe blackleg symptoms (Perminow et al. 2013), while in the same year a strain was isolated from potato tubers (cv. Polaris) with severe symptoms of soft rot and later formally described as a new species, $P$. polaris (Dees et al. 2017b).

In 2013, D. solani was isolated in Norway for the first time from a diseased potato plant sampled in a quarantine field where imported seed potatoes were grown (Perminow et al. 2013), and new isolations were made in 2015. In both cases, the Norwegian Food Safety Authorities were involved in an eradication program, including destruction of potato material. In a recent large-scale study of insects connected to potato fields throughout Norway, more than 90 distinct insect species were found to carry Pectobacterium spp. demonstrating the ubiquitous nature of the SRP (Rossmann et al. 2018).

\subsubsection{Poland}

Poland is one of the biggest producers of potato worldwide and the biggest in Europe. To assess losses caused by SRP in Poland, long-term population studies were performed. Potatoes showing symptoms of blackleg or soft rot are collected annually from seed crops in various Polish regions and monitored for SRP species. In addition, symptomless seed potatoes and approximately 2500 waterways were also tested for the presence of Dickeya spp. To accomplish these tasks, an accurate, high-throughput method based on multiplex PCR was developed aiming at the simultaneous screening of potato and water samples for most common SRP species (Potrykus et al. 2014). 
The first large-scale studies on the SRP population structure in Poland were performed on isolates from blackleg diseased potato plants obtained from seed crops in the growing seasons 1996 and 1997. These studies indicated that about $57 \%$ of the isolated bacteria belong to $P$. atrosepticum and the rest to $P$. carotovorum (Sledz et al. 2000). Further monitoring has been performed every 2 or 3 years thereafter. About 200 samples of diseased plants have been collected per year. Based on biochemical methods, physiological tests and multiplex PCR in 2013 and 2014, 26 to 38\% of the isolates were identified as $P$. atrosepticum, while the other two largest groups belonged to $P$. carotovorum (from 31 to $36 \%$ ) and P. parmentieri (from 22 to $32 \%$ ) (Waleron et al. 2002; Sławiak et al. 2013; Potrykus et al. 2016; Dees et al. 2017b; Motyka et al. 2017; Zoledowska et al. 2018) (Fig. 7.3). The majority of the P. atrosepticum isolates were derived from potato stems with blackleg symptoms and not from the tubers. The study further showed that $P$. parmentieri had been an important constituent of the SRP population in Poland as early as 1996, although it was then identified as $P$. carotovorum. The detailed characterization of about 100 strains of $P$. parmentieri, collected in 2013 and 2014 in Poland, revealed the presence of 5 different rep-PCR profiles (Zoledowska et al. 2018). As well as the above species, isolates of P. brasiliense were also sporadically detected (Waleron et al. 2015). In 2005, Dickeya was detected for the first time on seed potato in Poland. In all surveys, strains of $D$. solani were more often detected than D. dianthicola (Sławiak et al. 2009b; Potrykus et al. 2016). The monitoring of seed potato crops (2009-2013) indicated that Dickeya strains are present in 2-14\% of potato samples with blackleg and soft rot symptoms (Potrykus et al. 2016). Characterization of D. solani strains isolated from 2005 to

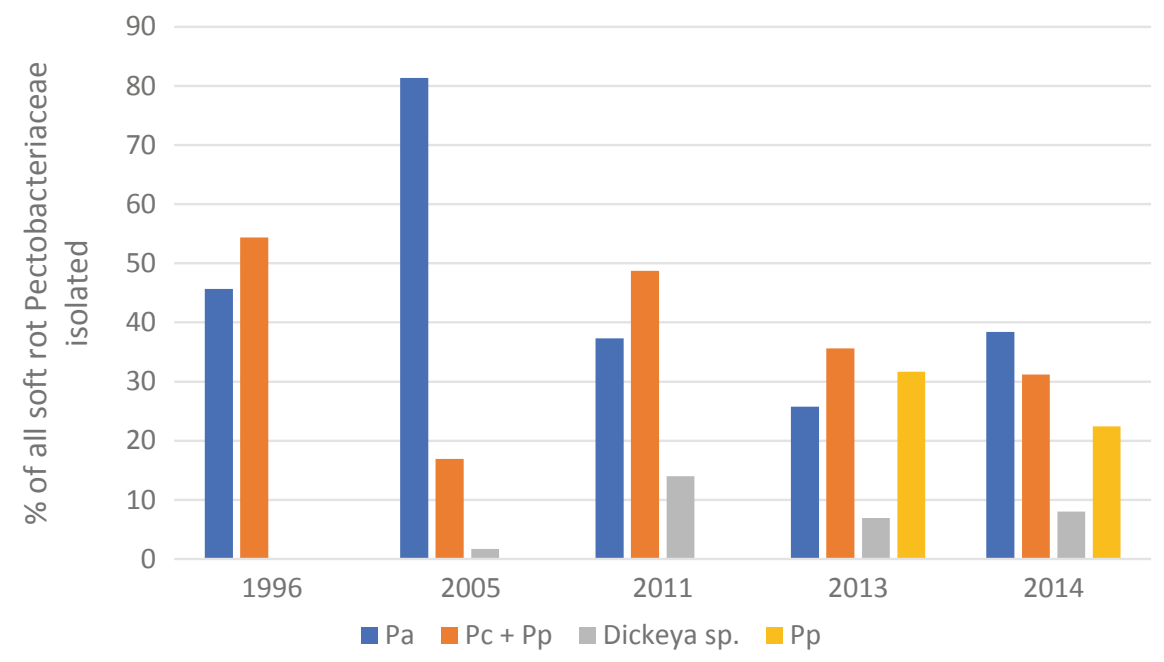

Fig. 7.3 Distribution of soft rot Pectobacteriaceae species isolated from blackleg diseased potato plants in Poland between 1996 and 2014. $\mathrm{Pa}=$ Pectobacterium atrosepticum, $\mathrm{Pc}=P$. carotovorum, $\mathrm{Pp}=$ P. parmentieri 
2016 using BOX, ERIC, REP-PCR and PFGE methods confirmed a high homogeneity of the isolated strains. Recent surveys on blackleg diseased plants indicate the presence of multiple species in the same plant (Motyka-Pomagruk, University of Gdansk, unpublished results). Most common were co-infections with P. atrosepticum and P. parmentieri. Surveys of surface waters, conducted from 2010 to 2013 indicated the presence of $D$. zeae and D. chrysanthemi in about $1 \%$ of the samples (Potrykus et al. 2016).

\subsubsection{Russian Federation and Some Post-Soviet Republics}

Several tens of millions tonnes of potato and vegetables are produced each year in the Russian Federation and Post-Soviet Republics. Around 6-10\% (in some regions up to $40 \%$ ) of this crop is lost due to phytopathogens, with SRP species being among the most devastating (Anonymous 2018b). These pathogens affect potato as well as sugar beet, cabbage, soybean and sunflower (Table 7.3).

Despite considerable economic damage caused by SRP in the Post-Soviet region, the number of surveys and investigations on SRP are relatively scarce (Khodykina et al. 2016; Ignatov et al. 2018). Nevertheless, available information indicates that during the last 20 years two changes in dominant SRP genera have taken place in Russia and several Post-Soviet Republics.

At the turn of this century, P. atrosepticum and P. carotovorum were mainly responsible for soft rot in field crops and during storage (Bakay 2014; Lazarev et al. 2017). However, from 2000 onward, the first blackleg incidences caused by $D$. dianthicola and D. solani occurred in Russia and Belarus (Karlov et al. 2010, 2011; Lazarev 2013; Ignatov et al. 2014; Komar et al. 2014). The genome sequences of Russian Dickeya isolates and European/American strains are highly similar, indicating that these strains are likely to have been introduced into the Post-Soviet region with (seed) potato tubers imported from Western countries (Vinogradova et al. 2014). Between 2009 and 2013 each year, a two-fold increase in incidence of Dickeya spp. infected potatoes was registered in Russia, resulting in an increase from 3 to $28 \%$ (Ignatov et al. 2015). To date, plant diseases caused by Dickeya spp. have been registered in all regions of Russia and several Post-Soviet Republics, including Belarus, Ukraine and Moldova (Moroz and Patika 2011; Komar et al. 2013; Zaitsev et al. 2016).

The second change in dominant SRP species occurred in 2017. In potato samples harvested early in the first decade of the twenty-first century, $P$. parmentieri and $P$. brasiliense started to increase in importance, with $P$. brasiliense becoming the dominant species in 2017 and 2018 (Ignatov et al. 2018; Ngoc Ha et al. 2019; Voronina et al. 2019). P. brasiliense was found in $>20 \%$ of the potato seed stocks and was responsible for $49 \%$ of all SRP species detected in potato during this period (Voronina et al. 2019). The second and third most often isolated Pectobacterium spp. are $P$. parmentieri and P. carotovorum, respectively (Voronina et al. 2019; $\mathrm{Ngoc} \mathrm{Ha}$ et al. 2019). Interestingly, Dickeya spp. were barely detected in Russia between 2017 and 2018 (Barannik et al. 2018; Voronina et al. 2019). Thus, during the last 20 years in 
Table 7.3 Incidents of SRP-caused plant diseases in Russia and some Post-Soviet Republics

\begin{tabular}{|c|c|c|c|c|}
\hline Host plant & Disease & Pathogen & Region & References \\
\hline \multirow[t]{6}{*}{ Potato } & $\begin{array}{l}\text { Blackleg, latent } \\
\text { infections }\end{array}$ & P. atrosepticum & $\begin{array}{l}\text { European, } \\
\text { Siberian and Far } \\
\text { Eastern regions of } \\
\text { Russia, Ukraine, } \\
\text { Belarus, } \\
\text { Lithuania, } \\
\text { Estonia, Latvia, } \\
\text { North Caucasus, } \\
\text { Moldova, } \\
\text { Kazakhstan, } \\
\text { Central Asian } \\
\text { republics }\end{array}$ & $\begin{array}{l}\text { Bakay (2014); } \\
\text { Zaitsev et al. } \\
\text { (2016); Lazarev } \\
\text { et al. (2017) }\end{array}$ \\
\hline & $\begin{array}{l}\text { Blackleg, Stem } \\
\text { rot disease }\end{array}$ & P. brasiliense & $\begin{array}{l}\text { Central European } \\
\text { region of Russia }\end{array}$ & $\begin{array}{l}\text { Ignatov et al. } \\
\text { (2018) }\end{array}$ \\
\hline & Soft rot & P. carotovorum & $\begin{array}{l}\text { European, } \\
\text { Siberian and Far } \\
\text { Eastern regions of } \\
\text { Russia, Ukraine, } \\
\text { Belarus, } \\
\text { Lithuania, } \\
\text { Estonia, Latvia, } \\
\text { North Caucasus, } \\
\text { Moldova, } \\
\text { Kazakhstan, } \\
\text { Central Asian } \\
\text { republics }\end{array}$ & $\begin{array}{l}\text { Bakay (2014); } \\
\text { Lazarev et al. } \\
\text { (2017) }\end{array}$ \\
\hline & Stem rot disease & P. parmentieri & $\begin{array}{l}\text { Central European } \\
\text { region of Russia }\end{array}$ & $\begin{array}{l}\text { Panicheva et al. } \\
\text { (2018) }\end{array}$ \\
\hline & $\begin{array}{l}\text { Soft rot, latent } \\
\text { infections }\end{array}$ & D. dianthicola & $\begin{array}{l}\text { All regions of } \\
\text { Russia, Belarus }\end{array}$ & $\begin{array}{l}\text { Zaitsev et al. } \\
\text { (2016); Komar } \\
\text { et al. (2014) }\end{array}$ \\
\hline & $\begin{array}{l}\text { Watery rot, } \\
\text { latent infections }\end{array}$ & D. solani & $\begin{array}{l}\text { All regions of } \\
\text { Russia }\end{array}$ & $\begin{array}{l}\text { Zaitsev et al. } \\
\text { (2016) }\end{array}$ \\
\hline Sunflower & Stem rot disease & $\begin{array}{l}\text { P. carotovorum, } P \text {. } \\
\text { atrosepticum, } D . \\
\text { dianthicola }\end{array}$ & $\begin{array}{l}\text { Central European } \\
\text { region of Russia, } \\
\text { Ukraine, Moldova }\end{array}$ & $\begin{array}{l}\text { Matveeva et al. } \\
\text { (2008); Moroz and } \\
\text { Patika (2011); } \\
\text { Borodin et al. } \\
\text { (2012) }\end{array}$ \\
\hline Soybean & Bacteriosis & P. carotovorum & $\begin{array}{l}\text { Southern region } \\
\text { of Russia, } \\
\text { Ukraine }\end{array}$ & $\begin{array}{l}\text { Podkina (2005); } \\
\text { Komok (2017) }\end{array}$ \\
\hline
\end{tabular}


Table 7.3 (continued)

\begin{tabular}{l|l|l|l|l}
\hline Host plant & Disease & Pathogen & Region & References \\
\hline Cabbage & $\begin{array}{l}\text { Slimy } \\
\text { bacteriosis }\end{array}$ & P. carotovorum & $\begin{array}{l}\text { European, } \\
\text { Siberian and Far } \\
\text { Eastern regions of } \\
\text { Russia, Central } \\
\text { Asian republics, } \\
\text { Belarus, Ukraine, } \\
\text { Republic of } \\
\text { Moldova, } \\
\text { Georgia, } \\
\text { Kazakhstan }\end{array}$ & $\begin{array}{l}\text { Lazarev et al. } \\
\text { (2017) }\end{array}$ \\
\hline Sugar beet & $\begin{array}{l}\text { Vascular } \\
\text { bacteriosis }\end{array}$ & P. betavasculorum & $\begin{array}{l}\text { Southern region } \\
\text { of Russia }\end{array}$ & $\begin{array}{l}\text { Panicheva et al. } \\
\text { (2017) }\end{array}$ \\
\hline $\begin{array}{l}\text { Onion } \\
\text { Bacteriosis }\end{array}$ & P. carotovorum & $\begin{array}{l}\text { Southern region } \\
\text { of Russia, } \\
\text { Moldova }\end{array}$ & $\begin{array}{l}\text { Tzerkovnaia } \\
\text { (2011) }\end{array}$ \\
\hline $\begin{array}{l}\text { Birch, conifers, } \\
\text { other wood } \\
\text { plants }\end{array}$ & $\begin{array}{l}\text { Bacterial dropsy } \\
\text { (wetwood) }\end{array}$ & $\begin{array}{l}\text { 'Erwinia } \\
\text { multivora' } \\
\text { Scz.-Parf }\end{array}$ & $\begin{array}{l}\text { European, } \\
\text { Siberian and Far } \\
\text { Eastern regions of } \\
\text { Russia, Ukraine, } \\
\text { Belarus, } \\
\text { Lithuania, Estonia } \\
\text { and Latvia, North } \\
\text { Caucasus, } \\
\text { Kazakhstan }\end{array}$ & $\begin{array}{l}\text { Tatarintsev (2014); } \\
\text { Cherpakov (2017); } \\
\text { Kalinichenko et al. } \\
\text { (2017) }\end{array}$ \\
\hline
\end{tabular}

the Post-Soviet region, SRP populations in potato have changed considerably, most likely due to transnational trade in potato tubers.

Vegetable crop production in the Post-Soviet region is also affected by Pectobacterium spp. and rarely by Dickeya spp. $P$. betavasculorum, a close relative of $P$. atrosepticum, causes a vascular disease of sugar beet in the Southern parts of Russia (Panicheva et al. 2017). Infection by $P$. carotovorum results in the development of a slimy rot of Brassicaceae widely distributed in the Post-Soviet region (Lazarev et al. 2017). This species also causes disease on soybean and onion in the Southern part of Russia, Ukraine and Moldova (Podkina 2005; Tzerkovnaia 2011; Komok 2017). Sunflower stem rot caused by $P$. atrosepticum, . carotovorum, and rarely by D. dianthicola, is found in the European part of Russia, in the Ukraine and Moldova (Matveeva et al. 2008; Moroz and Patika 2011; Borodin et al. 2012). Pectobacterium spp. also cause disease or colonize vegetable and ornamental plants grown in greenhouses, e.g. celery, asparagus, pepper, tomato, cucumber, melon, hyacinth, iris (Lazarev et al. 2017).

Soft rot-like diseases of wood plants are also frequently reported in the territory of the Post-Soviet region, namely Russia (especially the taiga area), Belarus, Ukraine, Kazakhstan, and Baltic Republics) (Tatarintsev 2014; Cherpakov 2017; Kalinichenko et al. 2017). This disease known as bacterial dropsy or wetwood or wood flooding 
is especially pronounced on birch and is also found on conifers, garden trees and some other wood species (oak, beech, elm, linden, ash, poplar). Wetwood disease covers wide territories (up to more than $30 \%$ of forests of Far East, Siberia, Ural, Caucus) affecting up to $40 \%$ of birch trees in some of the territories (Tatarintsev 2014). This problem is of great importance for Russia since forests occupy over $45 \%$ of the country territory and constitute $20 \%$ of the world wood store.

The disease usually starts from the wet necrosis of inner bark; the wet "core" may remain in the inner trunk area for decades or possibly even centuries without external disease manifestation. In some cases, wet necrosis of trunk exterior parts takes place. Among the factors that contribute to disease development are a high moisture, a low soil drainage, the softness of wood (the "softer" the wood the more susceptible it is to disease) and the age of the tree (the elder trees are more susceptible) (Sheluho and Sidorov 2009; Tatarintsev 2014).

In Russia, the causal agent of wetwood disease was isolated and identified in the 1960 as 'Erwinia multivora'. 'E. multivora' isolates were shown to cause wetwood disease after plant inoculation and demonstrated to be polyphagic: the isolates obtained from one species caused the symptoms on other ones (Cherpakov 2012). Surprisingly, despite the high importance of these bacteria in Russia, they have never been fully classified using and the actual taxonomy for ' $E$. multivora' remains unclear. By their cultural characteristics, however, 'E. multivora' appears identical to $P$. carotovorum (Cherpakov 2016, 2017). In particular, 'E. multivora' produces pectinases and cellulases and causes destruction of the middle lamella and tissue maceration. Consequently, there is an opinion that 'E. multivora' is a subspecies of $P$. carotovorum adapted to colonize wood plants.

\subsubsection{Sweden}

In Sweden in 2018, 23813 ha were used for potato production, of which 964 ha were seed potatoes (Anonymous 2018a, b). The certification scheme in Sweden includes field inspections for blackleg: two times in basic seed and one time in certified seed. In addition, a post-harvest visual examination of tuber samples for soft rot is conducted.

Surveys of bacteria causing blackleg symptoms in potato fields were performed in Sweden in the 1980s and showed that P. atrosepticum was dominant (Persson 1988). As seed trades have changed a lot in recent decades through Sweden becoming a member of the EU (1995), the importation of seed potatoes has increased significantly. Therefore in 2010-2012 a new study was initiated. A total of 203 seed lots were analysed. Results showed that $P$. atrosepticum is still very common in Swedish potato seed lots (ca $58 \%$ of seed lots), while Dickeya spp., including D. solani and occasionally D. dianthicola (ca $12 \%$ ), and P. parmentieri and P. carotovorum $(65 \%)$ were also present. Analyses of 103 stems with blackleg symptoms showed that all of these species cause blackleg disease in the Swedish climate. Frequently, more than one blackleg causing bacterial species was simultaneously present in plant material. Analyses of tubers without symptoms, mainly grown for seed, showed the presence 
of D. solani, D. dianthicola, P. atrosepticum, P. parmentieri and P. carotovorum. Detection of $P$. brasiliense was not included in this study (Persson and Rölin 2014).

In 2018, blackleg stems were collected from a ware potato field in Central Sweden and analysed using real-time Taqman ${ }^{\circledR}$ assays. The results show that both $D$. solani and $P$. parmentieri were detected in all four sub-samples. In one sub-sample of a plant grown from an imported seed tuber, $P$. brasiliense was detected (unpublished results, De Haan, NAK, Emmeloord the Netherlands) and is the first observation of $P$. brasiliense in potatoes grown in Sweden.

\subsubsection{Switzerland}

Potato blackleg has for many years been one of the main phytosanitary challenges for potato production in Switzerland. In the certification process, blackleg is the prime reason for rejection of seed lots during field inspection. The economic impact of the SRP on potato production in Switzerland is covered in more detail in Chap. 8.

Figure 7.4 shows results from a survey of all blackleg and stem rot diseased potato samples analysed at Agroscope from 1986 to 2018 and at the HAFL from 2012 to 2016. Over this period, Dickeya spp. (regardless of species, dianthicola or solani) were the dominant blackleg causing agents until 2012/13. During this period, $P$. atrosepticum was found only infrequently in blackleg diseased plants, and only during cold springs (Cazelles und Schwaerzel 1992), while P. carotovorum was frequently found. However, only specific assays for P. atrosepticum were available and all strains identified as belonging to the Pectobacterium genus but not P. atrosepticum

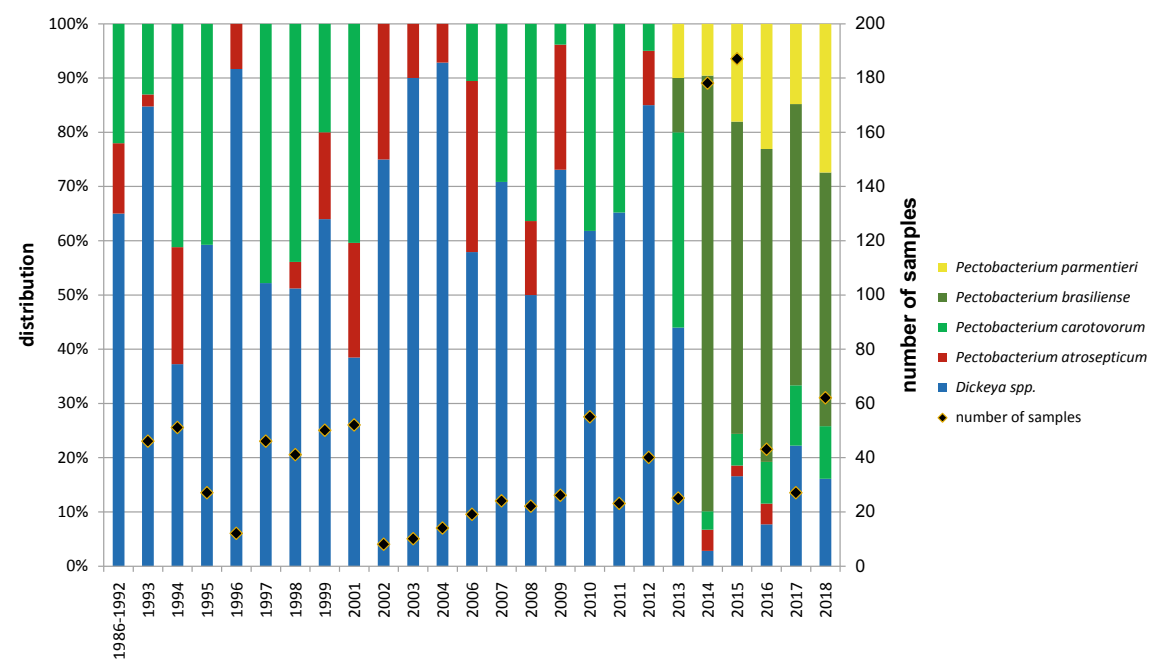

Fig. 7.4 Distribution of soft rot Pectobacteriaceae species in blackleg-diseased plants in Switzerland in the period 1993 to 2018 
were classified by default as $P$. carotovorum. No data are available on the impact of each bacterium on yield loss and on rejection of seed lots in the certification scheme. However, some data suggest that under Swiss climate conditions blackleg causing Dickeya spp. are more aggressive than blackleg causing Pectobacterium spp. (Linder 2016), which could explain the high prevalence of Dickeya spp. at least until 2012.

Since 2012, a shift in bacterial species has been observed, with Dickeya spp. being rarely observed and $P$. brasiliense appearing and then becoming more dominant as the main blackleg causing organism (de Werra et al. 2015a). It was evidenced that both $P$. brasiliense and $P$. parmentieri were actually present in Switzerland before as early as the 1980 s but at that time identified as $P$. carotovorum. It is therefore likely that some of the $P$. carotovorum strains diagnosed before 2013 were $P$. brasiliense or $P$. parmentieri (de Werra et al. 2015b). The reasons for this shift in the bacterial population are still unclear. As Switzerland is dependent on the import of basic seed lots from neighbouring seed exporting countries, the incidence of SRP tends to mirror the situation in there. Climate change may also affect a change in dominant species, while intensive efforts in recent years to improve the quality of seed lots against Dickeya spp. by seed testing may have paved the way for other bacteria, including P. brasiliense, to predominate.

\subsubsection{The Netherlands}

The Netherlands is the biggest exporter of agricultural goods after the United States making the Dutch agri-sector globally a major player. In 2017, the total value of Dutch agricultural exports was 91.7 billion euro (Source, Statistics NetherlandsCBS). Various important crops are affected by SRP including food crops such as potato, chicory and sweet pepper but also a number of ornamental crops including Phalaenopsis, Hyacinthus, Yucca, Sedum, Dahlia, Iris, Muscari, Freesia and Zantedeschia. The economic damage caused by SRP as broad host range pathogens in total is therefore considerable.

\subsubsection{Potato}

Between 2003 and 2007, the average annual costs ascribed to SRP in seed potatoes was estimated at 22 million euro, mainly as a result of down grading and rejection of seed lots (Prins and Breukers 2008). Seed testing is solely based on field inspections, with a zero tolerance for pre-basic and basic seed. In recent years, pre-basic seed was also tested in a multiplex TaqMan assay, which showed that a high percentage of seed lots are infected without showing symptoms in the field. In the assay, four composite samples of 50 tubers are analysed for the presence of $P$. atrosepticum, P. brasiliense, P. parmentieri and Dickeya spp. (Kooman, NAK, Emmeloord, The Netherlands, pers. comm.). The test has been compulsory for pre-basic seed, which is used by the sector to increase knowledge on the distribution of various SRP species and the level 
of latent infections but results had no consequences for the farmer. Losses during cropping and storage of ware- and processing potatoes are also found but there are no reliable data present on economic damage.

Surveys on blackleg and stem rot diseased plants show that SRP responsible for disease expression change over time. Before 1993, P. atrosepticum, P. parmentieri and $D$. dianthicola were found to be the dominant blackleg causing organisms. Between 1997 and 2012, D. solani became responsible for an estimated 70\% of diseased plants. In the last five years, D. solani has been overtaken by P. brasiliense, which counts now for $70-80 \%$ of the disease incidences, with a low percentage of $P$. parmentieri and $D$. solani. In the intensive agri-sector of the Netherlands, in which multiple crops are grown in a small region, the probability for introductions of new pathogen variants via contact with other host crops of SRP is high. It has been hypothesized that $D$. solani was introduced via contact with flower bulbs that can be infected with the same species (Sławiak et al. 2009a). Similarly, P. brasiliense, was recently isolated from hyacinth bulbs in the Netherlands possibly via contact with infected seed potatoes (Vreeburg, NAK, Emmeloord, The Netherlands, pers. comm.)

\subsubsection{Chicory}

In the Netherlands, occasionally, soft (leaf) rot due to infections with pectinolytic bacteria occurs in chicory but no data on economic losses have been published. Growth is done in aquaponics, which makes the crop vulnerable to infections. For management of the disease, treatments with $3 \%$ calcium chloride are applied prior to forcing heads by treating roots or, alternatively, developing heads are treated during forcing. In Europe, leaf rot can be caused by P. carotovorum, P. odoriferum (Waleron et al. 2014) and Pseudomonas marginalis but $P$. atrosepticum strains are also occasionally found in association with leaf rot (data CFBP collection). A more damaging, internally located head rot is caused by $D$. dianthicola and D. chrysanthemi.

\subsubsection{Sweet Pepper}

In 2012, Dutch growers of sweet peppers encountered high losses due to fruit rot caused by $P$. carotovorum both during plant growth and particularly post-harvest but losses were not quantified (De Vries et al. 2013). The bacteria were detected in soil particles, drain and condensation water, surfaces of sorting lines, plant stem tissue and root parts in the dropper. It was shown that fruit flies played an important role in dissemination of the pathogen. Effective management of the disease was realized by reducing the relative humidity, by sanitation measures (including disinfection of water), and by using dry and $\operatorname{cool}\left(7^{\circ} \mathrm{C}\right)$ storage conditions. Since then, only minor losses have been reported. 


\subsubsection{Ornamentals}

In the Netherlands, soft rot causes high levels of damage in various ornamental crops (Van Doorn et al. 2011; Slootweg et al. 2015). In particular, bulbous ornamentals such as Hyacinthus, Dahlia, Iris, Muscari, Freesia, Ornithogalum and Zantedeschia can be affected. Various SRP species have been detected and/or isolated from the symptomatic ornamental crops in the Netherlands (Table 7.4). In a number of these crops, soft rot can also be caused by bacteria from other bacterial families, in particular Pseudomonaceae (Mikiciński et al. 2010).

For Sedum, a warm water treatment of planting material $\left(30 \mathrm{~min}\right.$ at $47{ }^{\circ} \mathrm{C}$ or $15 \mathrm{~min}$ at $50^{\circ} \mathrm{C}$ ) was shown to be effective in reducing the disease (Slootweg et al. 2015). However, for other ornamental crops these high temperatures easily result in plant damage.

\subsubsection{Turkey}

In 2015, SRP species were isolated from approximately 50 blackleg diseased potato plants growing in different fields of commercial potato production areas in Samsun, Amasya, Corum and Yozgat provinces (Ozturk et al. 2018). Biochemical and molecular characterization, including the use of multiplex PCR and species-specific PCR, identified the causative agents as $P$. atrosepticum, $P$. brasiliense, $P$. carotovorum and P. parmentieri. Blackleg diseased potatoes may pose a threat to other crops that can host SRP, including tomato, pepper, cucumber, onion, cabbage, broccoli and sugar beet, as they are cultivated in the same provinces (Ozturk et al. 2018) but also in sunflower and artichoke. In sunflower, heavy losses with high disease incidences of

Table 7.4 Presence of different Dickeya and Pectobacterium species in ornamental plants in the Netherlands (Slootweg et al. 2015)

\begin{tabular}{l|l}
\hline Soft rot Pectobacteriaceae & Plant genera \\
\hline D. solani & Hyacinth, Muscari \\
\hline D. dadantii & Freesia, Hyacinth, Ixis, Narcis \\
\hline D. dianthicola & $\begin{array}{l}\text { Campanula, Chrysanthemum, Dahlia, Delphinium, Dianthus, } \\
\text { Eryngium, Freesia, Helianthus, Hyacinthus, Iris, Muscari, Sedum }\end{array}$ \\
\hline D. chrysanthemi & Begonia, Chrysant, Dahlia, Pastinaca \\
\hline Pectobacterium sp. & Caladium, Hosta, Iris, Sedum, Zantedeschia \\
\hline P. carotovorum & $\begin{array}{l}\text { Aubrieta, Calathea, Chrysanthemum, Cyclamen, Dieffenbachia, } \\
\text { Dracena, Freesia, Euphorbia, Iris, Kalanchoë, Osteospermum, } \\
\text { Spathiphyllum, Zantedeschia, Hyacinth }\end{array}$ \\
\hline P. atrosepticum & Zantedeschia \\
\hline P. aroidearum & Ornithogalum \\
\hline P. brasiliense & Hyacinth
\end{tabular}


$30 \%$ were found due to infections with $P$. atrosepticum, a pathogen that is rarely found in crops other than potato (Baştaş et al. 2009). In artichoke, P. carotovorum caused stem rot and pith necrosis with disease incidences of 10-15\% (Ustun and Arslan 2016).

\subsubsection{United Kingdom}

Potato is a major commodity in the UK, particularly in Scotland, with $80 \%$ of the UK's potato crops derived from Scottish seed. Approximately $45 \%$ of the potato growing area in Scotland is dedicated to seed production. Potato production in Scotland contributed approximately 240 million euro to the economy in 2017 , a $25 \%$ increase from 2015 (Anonymous 2018c).

Seed crops in the UK are certified on the basis of growing crop inspections. All crops are inspected at least twice during the growing season and they must meet strict tolerances in order to be certified. In Scotland, blackleg is the most common fault recorded during growing crop inspections and is the most common reason for downgrading or rejecting seed crops. An average of $6 \%$ of the seed area was downgraded or failed over the past 3 years. In the UK, there is no compulsory testing for Pectobacterium and Dickeya spp. in potato. An exception is the testing of seed potatoes for Dickeya spp. in Scotland and Northern Ireland.

Following an increase in recorded occurrences of Dickeya spp. in potatoes in European countries (Toth et al. 2011) and a finding of D. solani in two Scottish ware crops grown from non-Scottish seed in 2009, Scotland introduced a zero tolerance for all Dickeya species in the Scottish Seed Potato Classification Scheme (SPCS) from 2010. It is therefore now illegal to plant seed potatoes infected with Dickeya spp. in Scotland. All non-Scottish seed potatoes brought into Scotland, either for seed or ware productions, must be notified to the Scottish Government and seed should be tested for Dickeya spp. prior to planting. These crops are closely monitored during official inspections; stem samples are taken from crops showing blackleg symptoms to identify which species is the cause of disease. In addition to the crop inspections, the progeny of these crops are included in the annual statutory surveys for Ralstonia solanacearum and Clavibacter sepedonicus and also for the presence of Dickeya spp. in tubers. Further to this, a representative sample of Scottish seed crops is also included in the stem survey to ensure freedom from Dickeya spp. Like Scotland, Northern Ireland also has legislation which rejects any seed crop found to have Dickeya spp. Notification requirements are in force and all seed potatoes brought in from outside Northern Ireland or Scotland are tested for the pathogen prior to planting. This is followed up by inspections during the growing season where plants exhibiting blackleg symptoms are collected and tested. Lots found with Dickeya are not permitted to be planted and are either re-exported or destroyed. A finding in the growing crop will result in its rejection for seed or in processing the crop for ware under strict conditions. 
Table 7.5 Blackleg incidence and pathogens responsible for blackleg in Scotland

\begin{tabular}{l|l|l|l|l|l|l|l|l}
\hline & 2010 & 2011 & 2012 & 2013 & 2014 & 2015 & 2016 & 2017 \\
\hline \% seed stocks with blackleg & 31.5 & 49.2 & 52.7 & 32.3 & 42.3 & 29.3 & 44.7 & 43.8 \\
\hline $\begin{array}{l}\text { \% blackleg caused by } D . \\
\text { solani }\end{array}$ & 0 & 0 & 0 & 0 & 0 & 0 & 0 & 0 \\
\hline $\begin{array}{l}\text { \% blackleg caused by } D . \\
\text { dianthicola }\end{array}$ & 0 & 0 & 0 & 0 & 0 & 0 & 0 & 0 \\
\hline $\begin{array}{l}\text { \% blackleg caused by } P . \\
\text { atrosepticum }\end{array}$ & 93.8 & 96.3 & 95.5 & 96.4 & 96.8 & 95.2 & 96.3 & 93.8 \\
$\begin{array}{l}\text { \% blackleg caused by other } \\
\text { Pectobacterium spp.* }\end{array}$ & 6.2 & 3.7 & 4.5 & 3.6 & 3.2 & 4.8 & 3.69 & 6.18 \\
\hline
\end{tabular}

*P. carotovorum, P. brasiliense and P. parmentieri ( P. wasabiae)

Table 7.6 Blackleg incidence and pathogens responsible for blackleg in England and Wales

\begin{tabular}{l|r|r|r|l|r|r}
\hline & 2010 & 2011 & 2012 & 2013 & 2014 & 2015 \\
\hline \% seed stocks with blackleg & 32.1 & 21.5 & 33.8 & 23.4 & 23.4 & 23.7 \\
\hline \% blackleg caused by D. solani & 7.0 & 2.3 & 1.8 & 1.7 & 0.4 & 0.4 \\
\hline \% blackleg caused by D. dianthicola & 0.4 & 0.6 & 1.8 & 0 & 0.4 & 0.4 \\
\hline \% blackleg caused by P. atrosepticum & 75.2 & 74.4 & 84.1 & 86.5 & 93.6 & 89.4 \\
\hline \% blackleg caused by other Pectobacterium spp. * & 17.4 & 22.7 & 12.3 & 11.8 & 5.6 & 9.8 \\
\hline
\end{tabular}

*P. carotovorum, P. brasiliense and P. parmentieri ( P. wasabiae)

Results from the routine surveillance of seed crops in the UK indicate some differences in the pathogens responsible for blackleg in countries within the UK (Tables 7.5 and 7.6). Data from England and Wales were obtained from surveys conducted from 2010-2015 on behalf of the Agriculture and Horticulture Development Board (Potatoes), where bacteria from blackleg stems observed during official seed inspections were isolated and identified. In Scotland, $P$. atrosepticum is consistently the dominant species causing disease with $P$. carotovorum and $P$. parmentieri isolated from a small proportion of infected stems. This same trend is seen in Northern Ireland, with $96 \%$ of infection caused by $P$. atrosepticum and the remaining caused by $P$. carotovorum. In England and Wales, $P$. atrosepticum is also the dominant species in each year surveyed, although other pectinolytic bacteria ( $P$. carotovorum, P. brasiliense, $P$. parmentieri, D. solani or D. dianthicola) were isolated from between 6.4 and $25.6 \%$ of blackleg stems sampled (Tables 7.5 and 7.6). Most findings of Dickeya spp. and $P$. brasiliense in England and Wales were in seed stocks grown from seed originating in continental Europe, although there have also been isolated findings in England of D. solani, D. dianthicola and P. brasiliense in seed stocks produced from seed of UK origin. The presence of Dickeya spp. and P. brasiliense in England and Wales, but not Scotland, may be explained by the fact that England imports approximately $15 \%$ of its seed from continental Europe, whereas Scotland has not imported seed from the European continent since 2007 (SASA, unpublished data). Limited surveys 
in England and Wales have indicated the occasional finding of D. dianthicola, $D$. solani, D. zeae and D. aquatica in watercourses, although D. zeae and D. aquatica have never been isolated from potato in the UK.

\subsection{Asia}

\subsubsection{China}

In China, fewer varieties of vegetable crops were planted before 1980 and people residing in cities, especially in northern China, lived largely on preserved vegetables, including Chinese cabbage, potato, turnip and carrot from later autumn to early spring. Among these varieties of vegetables, both the planting area and yield of Chinese cabbage (Brassica rapa ssp. pekinensis) was the largest. Soft rot disease was common on plants growing in the field and during storage, which troubled agricultural administrators and affected family livelihood. However, pathogens were rarely identified and characterized. Since then, the famous historic economic system reformation was carried out in China. With the influence of the reformation on Chinese agriculture and logistics steadily intensifying, the number of varieties of vegetable crops increased sharply, and both the variety and scale of different ornamental plants and medical herbs were introduced. At the same time, Chinese cabbage planting was reduced in area as people living in northern cities began to access vegetables from supermarkets, thus relying less on vegetable preservation. Rotting of vegetables in local stores became less of a problem, although it was often still found on most vegetable crops and ornamental plants in the field. Since the 1980s pathogens causing decay were identified using physiological and biochemical methods. In 1982, Pectobacterium aroidearum causing soft rot disease on four medical herbs, including ginseng (Panax ginseng), rhizoma gastrodiae (Gastrodia elata), fritillary (Fritillaria spp.) and ginger (Zingiber officinale) was reported (Prof. Maofan Zhou,Huazhong Agricultural College, China,unpublished results). In 1984, P. carotovorum from the perennial herb Lysimachia foenum-graecumi was identified (Prof. Yuxin Chen, Guangxi Agricultural College, China, unpublished results). In 1985, 284 SRP isolates were identified from 33 samples of potato tubers collected from 23 provinces of China, of which 5.5, 10.2 and 5.3\% were P. carotovorum, Dickeya spp. and $P$. atrosepticum respectively, whereas $9 \%$ could not be identified up to species level (Prof. Jingsheng Wang, Nanjing Agricultural College, China, unpublished results). The Animal and Plant Quarantine Station of Shanghai isolated D. chrysanthemi from rotting cactus plants in 1989, which were planted in the closed observation garden after the second Holland Flower Exhibition in Shanghai at October 1987 with 10\% of them exhibited stem rot. In 2004, $16 \mathrm{~S}$ rDNA sequence analysis was first used to identify and characterize strains of SRP causing soft rot disease on Chinese cabbage (Yuan et al. 2004). 
More recently, numerous pectinolytic bacterial strains have been isolated from a variety of vegetable crops, medical herbs and ornamental plants, as well as from rice and pear trees in China. These include the following Pectobacterium spp.: $P$. carotovorum in potato (Zhang et al. 2012), tobacco (Wang et al. 2017), Pinellia ternata (Hu et al. 2007) and seleng wormwood (Tian et al. 2015); P. atrosepticum in potato (She et al. 2013); . aroidearum in Chinese cabbage (Xie et al. 2018); $P$. brasiliense in potato (Zhao et al. 2018) and cucumber (Meng et al. 2017). In addition, the following Dickeya spp. were isolated: D. zeae in banana (Zhang et al. 2014) and rice (Li et al. 2012); D. dadantii subsp. dieffenbachiae in Tagetes patula (Zhang et al. 2013) and Philodendron (Lin et al. 2012); D. dadantii subsp. dadantii in Anubias barteri var. nana (Wang et al. 2016); D. solani in imported Hyacinthus orientalis (Chen et al. 2015); D. fangzhongdai in pear trees (Tian et al. 2016); Dickeya spp. in poinsettia (Rungnapha et al. 2008) and Oncidium spp. (Li et al. 2009). For most of these results, $16 \mathrm{~S}$ rDNA sequence analysis was used to identify a range of different genera and species showing a wide geographic distribution and diversity of host plants in China.

In China, water supply is generally limited to suppress the occurrence of bacterial soft rot diseases but in areas of high soft rot incidence chemicals such as copper, chlorine dioxide, bismerthiazol and zinc thiazole are used on vegetable crops, medical herbs and ornamental plants, as well as streptomycin on ornamental plants. In addition, some attempts have been made to develop biological control agents for management of soft rot diseases, including Bacillus amyloliquefaciens subsp. plantarum (Zhao et al. 2013) and Myxococcus sp. (Li et al. 2018); both strains isolated from soil. Experimental work has been done on transgenic strains of Escherichia coli (Fan et al. 2011) and Lysobacter enzymogenes strain OH11 (Qian et al. 2010) expressing increased levels of the $N$-acyl homoserine lactone degradation protein. All of these strains offer some inhibition of soft rot development on plants, although only Bacillus has passed registration for use as a commercial biological control agent on rice in China.

\subsubsection{Iran}

In 2018, the agricultural export of Iran was approximately 6.13 million tonnes with a total value of 5.93 billion dollars (www.amar.org.ir). SRP were responsible for diseases on corn, rice, canola, sugar beet, potatoes, banana, dates, carrots, cabbage, onions, garlic, turnips, peppers, ornamental cactus, and species of Philodendron, Pandanus, Dieffenbachia, Cyclamen, Iris, Aglaonema, Dracaena, Gladiolus, Ficus, and Orobanche in the form of soft rot, black stems, bulb rot or leaf spots. Some varieties of field crops grown in Iran, including corn, tomatoes, potatoes and sugar beet, have a tolerance against SRP. 


\subsubsection{Potato}

Iran is the world's No. 12 potato producer and the fourth biggest in Asia, after China, India and Bangladesh. Potato is one of Iran's leading agricultural exports and the third most important food crop after wheat and rice, with a total production of ca 5 megatonnes and shipment about 0.5 megatonnes in 2018. Since 1961, production has increased more than 15 times. Bacterial soft rot caused by $P$. carotovorum is a major disease of potato crops across the temperate regions of Iran. Postharvest losses are due to inadequacy in packing and a lack of refrigeration facilities (Baghaee Ravari et al. 2013).

\subsubsection{Sugar Beet}

The areas under cultivation of sugar beet (Beta vulgaris L.) in Iran during 2017 were 126,400 ha yielding 8 megatonnes of root and 1.1 megatonnes of sucrose (www. amar.org.ir). Infections of sugar beet with $P$. betavasculorum have been reported, resulting in bacterial vascular necrosis and sugar beet root rot, although no data on economic losses are known (Fassihiani and Nedaeinia 2008). The pathogen was identified using whole-cell protein analysis by SDS-PAGE and physiological and biochemical assays.

\subsubsection{Ornamental Plants}

SRP have also been reported to affect ornamental plants, including Fritillaria imperialis (P. carotovorum) in Kermanshah and Isfahan (Mahmoudi et al. 2007). In the Mazandaran, Guilan, Golestan and Khorasan Razavi provinces soft rot diseases caused by SRP were reported on Epipremnum aureum, Ficus elastic, Maranta leuconeura, Sansevieria trifasciata, Schlumbergera bridgesii, Syngonium podophyllum and species of Aglaonema, Dieffenbachia, Hippeastrum, Iris, Lampranthus, Peperomia, Philodendron and Spathiphyllum (Baghaee-Ravari et al. 2011; Ravari et al. 2010). In greenhouses in Mahalat (Markazi province) soft rot (P. carotovorum) was found in Opuntia and Haworthia spp. (Baghaee-Ravari and Gerayeli 2015).

\subsubsection{Watermelon}

Iran is the 4th largest producer of watermelon (Citrullus lanatus) in the world. In 2012, a disease characterized by water-soaked lesions and soft rot was observed on mature and immature fruits of watermelon cv. Crimson sweet. Based on phenotypic characteristics and 16S rRNA sequence analysis, the causal organism was identified as $P$. carotovorum (Dana et al. 2015). 


\subsubsection{Israel}

\subsubsection{Potato and Vegetable}

In Israel, potatoes are produced almost all year round under semi-arid conditions with overhead irrigation. Seed tubers are imported from Europe for the spring season, and locally produced seed tubers grown during the spring are used for the fallwinter season. Soft rot diseases occur in both seasons, due to the prevailing climatic conditions that favor their development, especially with relatively high temperatures in April-May and September. Other vegetables, such as lettuce, parsley, carrot, onion, celery, broccoli, pepper, sweet potato, but also ornamentals can be affected by soft rot diseases. Until 2016, D. solani was the most dominant causal agent of potato soft rot diseases in Israel (Tsror et al. 2009, 2011, 2013), while in recent years, $P$. brasiliense has become the most prevalent pathogen (Tsror, Gilat, Israel, unpublished data), although $P$. parmentieri was also found to be responsible for blackleg in potato (Tsror et al. 2020). Soft rot diseases on other vegetables are caused by Pectobacterium spp., mainly by $P$. brasiliense and $P$. carotovorum (Tsror, Gilat, Israel, unpublished data). P. brasiliense has also been found on Malva nicaeensis, a common weed in potato fields in Israel (Tsror et al. 2019).

When imported seed crops from Europe are infected, the domestic (local) seed tubers that are produced during the spring will lead to infections and damage of the progeny tubers used for the winter crop (Toth et al. 2011; Tsror et al. 2011). Yield reductions of 20-25\% due to infections with SRP have been recorded on various potato cultivars (Tsror et al. 2011; Tsror et al. 2009). Inspectors of the Plant Protection and Inspection Services reported during the spring seasons of 2006-2012 that blackleg incidences in the fields were between 5 and $27 \%$ (on average $11 \%$ ), observed in farms producing 775 to 3500 tonnes (on average 2250 tonnes) of imported seeds. In some cases, even higher losses were encountered. In spring 2018, a reduction of 12 tonnes/ha was observed for cultivar Mozart that had $40 \%$ blackleg and soft rot in the field (Tsror, Gilat, Israel, unpublished data). In the winter season, tuber soft rot occurs mainly in early planting (September), with severe damage leading to rotting of more than $50 \%$ of seed in a field and, in case of high losses, replanting is necessary. Certain cultivars, which have been identified as highly susceptible to Dickeya spp. under Israeli conditions, are now being imported to a much lesser extent (Toth et al. 2011).

D. solani is still considered as a quarantine organism in Israel, with zero tolerance. Nevertheless, testing of imported seed lots is carried out on grower demand, enabling the selection of better quality imported seed for use in the local seed production in the fall-winter crop. For each seed lot, four composite sub-samples of 50 tubers each (a total of 200 tubers per lot) are used. Detection of latent infections with SRP is done as previously reported (Tsror et al. 2011; Van der Wolf et al. 2017). The most promising approach to control soft rot diseases is to avoid the use of latently contaminated seed lots, and laboratory testing is the only way to detect seed infections prior to planting. It is especially important in Israel, because the environment is very conducive for 
symptom development. Therefore, the imported seed lots with the lowest infection pressure are used for the winter production.

\subsubsection{Ornamental Plants}

Ornamental plants in the Mediterranean basin, which has a climate characterized by mild rainy winters and hot dry summers, are produced in the winter season in order to meet the European market demands for fresh flowers during the cold season. The most important ornamental hosts are Zantedeschia sp. (tuber plant) and Ornithogalum sp. (flower bulbs) from the Aracea and Asparagaceae families, respectively. In both crops several species and cultivars display variable degrees of soft rot susceptibility (Wright 1998; Yishay et al. 2008; Snijder et al. 2004). In the genus Ornithogalum, $O$. dubium is the most susceptible species, while $O$. thyrsoides displays relative resistance (Lipsky et al. 2016). In the genus Zantedeschia, Z. aethiopica with white flowers is relatively resistant whereas several colored yellow/orange varieties are more susceptible (Snijder et al. 2004). Nevertheless, some cultivars of Z. aethiopica such as "Coloumn de la Peache" are more sensitive to the bacteria than others such as cultivar "Innocence" or "Israeli Calla", with differences of 60-95\% survival in the field (Snir and Luria 2009). Other crops that are occasionally reported as affected by soft rot are Ranunculus asiaticus and several tropical foliage crops from the family Araceae, including Dieffenbachia spp. and Syngonium spp. Symptoms may appear anywhere on the plant, with water-soaked lesions occurring on leaves, stems and plant bulbs or tubers. The major pathogens responsible for soft rot in ornamental plants in Israel are $P$. aroidearum and $P$. carotovorum, which have been isolated from several bulb crops through the years (Yishay et al. 2008).

Flower bulbs are produced during the winter months in greenhouses or covered tunnels to guarantee climate control irrespective of weather conditions. Plants are grown in a soilless medium containing mixtures of volcanic ash, peat moss and coir (coconut fiber). These conditions are highly conducive for soft rot bacteria with average temperatures ranging from $10-25^{\circ} \mathrm{C}$ night/day and a relative humidity of 80 $100 \%$. Consequently, spread of soft rot disease can be rapid, and once the production facility is affected, crop losses may reach 10-60\% (Iris Yedidia, Volcani Center, Israel, personal communication). Since irrigation is based mainly on drip irrigation or sprayers during the early season, this may further increase bacterial spread within the flower beds.

Control of soft rot diseases is based almost exclusively on sanitation and cultural recommendations. The soilless medium is disinfected between growing seasons and replaced every few years. As the primary mechanism of pathogen dispersal within the nursery is through irrigation water and contaminated soil and tools, flower harvest includes strict regulations for sanitation of the cutting equipment and other tools. The most effective way to reduce soft rot dispersal in commercial greenhouses is to use clean propagation material via tissue culture. Tissue culture propagation is common for Zantedeschia sp. hybrids and some Ornithogalum sp. cultivars. However, due to the high cost of tissue culture, the application is to a very limited extent. 


\subsection{Australia and Oceania}

In Australia, potato is the country's most important agricultural crop. In 2017, the production was 1.1 megatonnes from 28,000 hectares (www.potatopro.com/nl). $P$. carotovorum and $P$. atrosepticum have been found in association with potato tubers (Peltzer and Sivasithamparam 1988). The pathogens were isolated from the potato ecosystem, including water and soil (Peltzer and Sivasithamparam 1988). There are also records of $P$. brasiliense not only from potato but also from lettuce and capsicum (Australian Plant Diseases Database, https://collections.ala.org.au). Soft rot in potato tubers is further caused by $D$. zeae, but the pathogen was unable to produce blackleg symptoms in inoculated stems (Cother and Powell 1983). Dickeya spp. have also been isolated from two major river systems and their alpine sources in Australia (Cother and Gilbert 1990). As the pathogen could only survive for a limited period (7 months) in sterile water, it was speculated that the pathogen was a constituent of the sessile bacterial population on stream weeds and sediments. Recently, D. dianthicola was detected for the first time in Australia on an Australian potato growing property (Wright et al. 2018; Tesoriero 2018). It has been speculated that infections were transmitted from diseased dahlia tubers to seed potatoes grown as a follow-crop. The pathogen has since also been found in freesia bulbs. D. zeae was found on pineapples in Queensland (Tesoriero 2018). An unidentified Dickeya spp. was responsible for soft rot in ginger in Australia (Stirling 2002). In experiments, the pathogen caused a high percentage of rot under high temperature conditions $\left(25-35^{\circ} \mathrm{C}\right)$ and in watersaturated soils. $P$. carotovorum has caused wet rot problems in cyclamen after a period of slump due to infections with Fusarium wilt, causing up to $20 \%$ mortality of plants in nurseries (Chandrashekar and Diriwaechter 1983).

In New Zealand, around 525,000 tonnes of potatoes are produced by 200 growers on an area of ca. 10.000 hectares (https://potatoesnz.co.nz). Potato blackleg is mainly caused by $P$. atrosepticum (Pitman et al. 2008) and P. brasiliense (Panda et al. 2012), while P. carotovorum (Pitman et al. 2008) and P. parmentieri (Pitman et al. 2010) have been reported as causative agents of soft rot in potato tubers. Dickeya spp. have also been isolated from blackleg diseased potato plants in New Zealand and also from carrots (Pitman et al. 2008). P. carotovorum has been found in association with soft rot in calla lily (Zantedeschia sp.) (Wright 1998).

\subsection{Africa}

Pectobacterium and Dickeya spp. have been reported on various crops in Africa, including banana, cassava, garlic, maize, melon, onion, potato, sesame, tomato, and sunflower (Table 7.7). There is, however, limited information and these pathogens are only known to occur in 17 of the 54 African countries. The majority of these reports are from South Africa. As potatoes are one of the staple food crops in Africa, 
much of the information available is on this host. Only 18 crops and 11 ornamentals are reported hosts of SRP in Africa.

The host range, distribution and SRP present in Africa according to published records are in most cases based solely on observations, which is strongly affected by economic and social factors (Bebber et al. 2014). Notably, though, there are no reports of $P$. betavasculorum, $P$. cacticida, $D$. dadantii subsp. dieffenbachiae, $D$. paradisiaca or $D$. solani on the continent. This, however, is not necessarily proof that these pathogens are not present in Africa, rather that they may be present but have not yet been detected. Nonetheless it is important for regulatory bodies to ensure that good phytosanitary measures are in place and are enforced to ensure that they are not accidentally introduced.

Potatoes are planted year-round in many African countries, but soft rot and blackleg occurrence is highest during summer plantings in rainy seasons. The majority of research on SRP in southern Africa has been done in South Africa and to a lesser extent in Zimbabwe (Van der Merwe et al. 2010; Ngadze et al. 2012). The primary pathogen causing soft rot and blackleg in these countries is $P$. brasiliense (Van der Merwe et al. 2010; Ngadze et al. 2012). The commercial South African potato industry has a well-functioning, high-level seed potato industry, which ensures that stringent requirements are met in the production and certification of seed potatoes. Basic hygiene measures are put into place by commercial growers to reduce the incidence of soft rot and blackleg. These include cultural measures such as avoiding excessive irrigation and planting in poorly drained fields, shallow planting when ambient temperatures are $<30{ }^{\circ} \mathrm{C}$, a $>3$-year crop rotation programme with nonhosts, removal of volunteer plants, and sufficient calcium fertilisation. Harvest and post-harvest measures include limiting mechanical damage during harvest, grading and transport, removal of visually infected tubers before harvest and during grading, ensuring good ventilation, low temperatures and good sanitation in grading sheds and packhouses, and regular replacement of water in case tubers are washed.

\subsection{Latin America}

Potato production is of significant economic importance in Latin America, with the highest productions per year in Peru with 4.6 megatonnes, Brazil with 3.6 megatonnes, Argentina and Colombia with 1.8 megatonnes and Mexico with 1.6 megatonnes (Caldiz et al. 2016). There are 60 major diseases that can affect the potato crop; 35 caused by fungi, 6 by nematodes, 12 by viruses and 7 by bacteria (Stevenson et al. 2001). Bacterial wilt caused by the Ralstonia solanacearum species complex and blackleg and soft rot caused by SRP are considered as the dominant bacterial diseases. However, in Latin America the information on bacterial soft rot diseases is limited. There is a need for surveys to identify and characterize the causal agents of soft rot diseases, for diagnostic methods to test plant propagation material and to extend knowledge on the epidemiology and on integrated management strategies to solve problems with SRP in Latin America. 
Table 7.7 Confirmed reports of soft rot Pectobacteriaceae species in Africa

\begin{tabular}{|c|c|c|c|}
\hline Pathogen & Reported from & Host & Reference \\
\hline \multirow[t]{4}{*}{$\begin{array}{l}\text { Dickeya } \\
\text { chrysanthemi }\end{array}$} & Egypt & Potato & $\begin{array}{l}\text { Ashmawy et al. (2015); } \\
\text { EPPO (2018) }\end{array}$ \\
\hline & South Africa & Potato & Serfontein et al. (1991) \\
\hline & & Banana & Gorter (1977) \\
\hline & $\begin{array}{l}\text { Algeria } \\
\text { Comoros } \\
\text { Democratic Republic } \\
\text { of the Congo (DRC) } \\
\text { Ivory Coast } \\
\text { Morocco } \\
\text { Sudan } \\
\text { Zimbabwe }\end{array}$ & Not defined & EPPO (2018) \\
\hline \multirow{2}{*}{$\begin{array}{l}\text { D. dadantii pv. } \\
\text { dadantii }\end{array}$} & South Africa & Potato & Ngadze et al. (2012) \\
\hline & Zimbabwe & Potato & $\begin{array}{l}\text { Ngadze et al. (2010); } \\
\text { Paradza et al. (2015) }\end{array}$ \\
\hline \multirow[t]{2}{*}{ D. dianthicola } & Zimbabwe & Potato & Ngadze et al. (2012) \\
\hline & Morocco & Potato & Oulghazi et al. (2020) \\
\hline \multirow[t]{3}{*}{ D. zeae } & South Africa & Maize & Pauer (1964) \\
\hline & Egypt & Maize & Sinha and Prasad (1977) \\
\hline & $\begin{array}{l}\text { Comoros } \\
\text { Mauritius } \\
\text { Sudan } \\
\text { Zimbabwe } \\
\end{array}$ & Not defined & CABI (2018) \\
\hline P. aroidearum & South Africa & Zantedeschia aethopica & Gorter (1977) \\
\hline \multirow[t]{6}{*}{ P. atrosepticum } & South Africa & Potato & Doidge (1919) \\
\hline & Algeria & Potato & $\begin{array}{l}\text { Agha and Fettotouche } \\
\text { (1991) }\end{array}$ \\
\hline & Egypt & Potato & Bradbury (1986) \\
\hline & Mauritius & Potato & $\begin{array}{l}\text { Autrey and Dookun } \\
\text { (1989) }\end{array}$ \\
\hline & $\begin{array}{l}\text { Morocco } \\
\text { Mozambique } \\
\text { Tanzania } \\
\end{array}$ & Potato & Bradbury (1986) \\
\hline & Zimbabwe & Potato & Ngadze et al. 2012 \\
\hline \multirow[t]{3}{*}{ P. carotovorum } & Morocco & Potato & Faquihi et al. (2015) \\
\hline & Ethiopia & Tomato, Sesame & $\begin{array}{l}\text { Lemma et al. (2014); } \\
\text { Korobko (1997); } \\
\text { Onkendi and Moleleki } \\
\text { (2014) }\end{array}$ \\
\hline & Kenya & Potato & Muturi et al. (2018) \\
\hline
\end{tabular}


Table 7.7 (continued)

\begin{tabular}{|c|c|c|c|}
\hline Pathogen & Reported from & Host & Reference \\
\hline & Cameroon & Tomato & Ambang et al. (2016) \\
\hline & Algeria & Potato & Naas et al. (2018) \\
\hline & Rwanda & Potato & $\begin{array}{l}\text { Nzabuheraheza and } \\
\text { Nyiramugwera (2015) }\end{array}$ \\
\hline & $\begin{array}{l}\text { Central African } \\
\text { Republic }\end{array}$ & Cassava & Daniel et al. (1981) \\
\hline & $\begin{array}{l}\text { Democratic Republic } \\
\text { Congo }\end{array}$ & Strelitzia reginae & $\begin{array}{l}\text { El-Goorani and Abo El } \\
\text { Dahab (1972) }\end{array}$ \\
\hline & Egypt & Melon & Saleh and Huang (1997) \\
\hline & & Garlic & Barakat et al. (1985) \\
\hline & & Onion & Saleh (1991) \\
\hline & & Sunflower & Ismail et al. (2012) \\
\hline & & Potato & El Zayat et al. (1978) \\
\hline & Libya & Potato & $\begin{array}{l}\text { Zayed and Maayouf } \\
\text { (1989) }\end{array}$ \\
\hline & Malawi & Tobacco & $\begin{array}{l}\text { Peregrine and Lyon } \\
(1975)\end{array}$ \\
\hline & & Potato & $\begin{array}{l}\text { Tanton and Abington } \\
(1979)\end{array}$ \\
\hline & Mauritius & Potato & $\begin{array}{l}\text { Autrey and Dookun } \\
\text { (1989) }\end{array}$ \\
\hline & South Africa & $\begin{array}{l}\text { Potato, tomato, onion, } \\
\text { carrot, } \\
\text { lettuce, cauliflower, } \\
\text { cabbage, turnip, } \\
\text { Japanese radish, melon, } \\
\text { Sedge, orchid (Cattleya } \\
\text { and Cymbidium spp.), }\end{array}$ & Gorter (1977) \\
\hline & & Tobacco & Terblanche (2009) \\
\hline & & $\begin{array}{l}\text { Clivia, bulbine, } \\
\text { agapanthus, wild ginger }\end{array}$ & Laing (2009a) \\
\hline & & Opuntia ficus-indica & Swart and Swart (2000) \\
\hline & & Watermelon & $\begin{array}{l}\text { Moloto and } \\
\text { Goszczynska (2007) }\end{array}$ \\
\hline & Sudan & Dahlia, freesia, iris & Laing (2009b) \\
\hline & & $\begin{array}{l}\text { Celery, parsley, Swiss } \\
\text { chard }\end{array}$ & $\begin{array}{l}\text { Jones and van der Walt } \\
(1987)\end{array}$ \\
\hline & Zimbabwe & Sunflower & $\begin{array}{l}\text { Abdel-Rahim and Adam } \\
\text { (1987) }\end{array}$ \\
\hline & & Tobacco & Hussain (1983) \\
\hline
\end{tabular}


Table 7.7 (continued)

\begin{tabular}{|c|c|c|c|}
\hline Pathogen & Reported from & Host & Reference \\
\hline & & Potato & Ngadze et al. (2012) \\
\hline \multirow[t]{6}{*}{ P. brasiliense } & South Africa & Potato & $\begin{array}{l}\text { Van der Merwe et al. } \\
(2010)\end{array}$ \\
\hline & Kenya & Potato & $\begin{array}{l}\text { Onkendi and Moleleki } \\
\text { (2014) }\end{array}$ \\
\hline & Algeria & Potato & Naas et al. (2018) \\
\hline & Egypt & Potato & Ashmawy et al. (2015) \\
\hline & Zimbabwe & Potato & Ngadze et al. (2012) \\
\hline & Morocco & Potato & Oulghazi et al. (2020) \\
\hline P. parmentieri & South Africa & Potato & Moleleki et al. (2013) \\
\hline P. polaris & Morocco & Potato & Oulghazi et al. 2020 \\
\hline P. versatile & Morocco & Potato & Oulghazi et al. (2020) \\
\hline
\end{tabular}

\subsubsection{Chile}

Soft rot, pre-emergence seed decay and blackleg are considered as important diseases in the seed potato production area, which is in the south of Chile and where seed crops are certified for the presence of blackleg. In recent years the area has been affected by re-emerging health problems, caused by both bacteria and viruses. Today, blackleg and soft rot are responsible for $24 \%$ of the rejections in potato seed production (Acuna et al. 2016). In studies conducted in the 1990s, in which blackleg and soft rot were highly prevalent, $P$. atrosepticum was the dominant causative agent (Acuna and Riffo 1993). The introduction of the tissue culture in the system of seed production has largely helped to reduce disease incidences.

In recent years, however, problems with bacterial diseases in the potato crop are increasing again. Several factors may be involved in this, including cultivation management, environmental conditions and the occurrence of infections with other 'new' SRP species. Samples tested in the south of Chile show that today P. carotovorum, which is more aggressive and has a higher optimum temperature, predominates. This change may be due to the predominance of warmer summers, along with the use of irrigation, given the water deficit that is present in the South of Chile. A recent survey shows that 13.5 and $64.8 \%$ of the strains causing the disease are $P$. atrosepticum and P. carotovorum, respectively (Acuna et al. 2017).

The Agricultural Service of Chile (SAG) reported disease incidences in potato in northern Chile (Coquimbo region) in an area of 3.9 ha, caused by D. solani in 2014, 2015 and 2017 and D. dadantii in 2015 and 2017. In 2016, D. dadantii was also found in potatoes in the southern part of the country on four sites with a total of 30 ha. Infested fields in Chili are put under official control and quarantine resolution (SAG 2016). 


\subsubsection{Mexico}

P. atrosepticum has been isolated from potato, D. chrysanthemi from carrot and $P$. carotovorum from nopal (Opuntia cacti) (Oliveira et al. 2003; González-Rodríguez et al. 2005). Recently, P. brasiliense was described as the causative agent of soft rot of cactus crops in México (Mejía-Sánchez et al. 2019). Ribas (2007) described pre-harvest field losses of potato crops in the field due to damage caused by Pectobacterium spp. as 10-40\%. However, during storage up to $100 \%$ losses were found. In 2002, for the first time $P$. brasiliense was identified as the causative agent of blackleg (Rommel and Duarte 2002), and was later characterized in more detail (Duarte et al. 2004). P. brasiliense was also detected in potatoes imported from Chile, Argentina and Uruguay indicating that the pathogen is widespread in Latin America.

\subsubsection{Other South American Countries}

In Peru, $P$. peruviense was identified as the causative agent of blackleg and soft rot in potato (Waleron et al. 2018). In Ecuador, under high humidity conditions, potato blackleg incidences exceeding $20 \%$ have been observed following infections by various Pectobacterium spp. In Argentina, $P$. carotovorum caused soft rot in Cynara scolymus L (Soto and Puglia 2002), in the ornamental plant Spathiphyllum wallisii (Alippi and López 2009) and in tomato crops (Alippi et al. 1997). In 2017, in Colombia P. brasiliense was found for the first time to infect tomato crops (Jaramillo et al. 2017), while in the state of Miranda in Venezuela, $P$. brasiliense was also found for the first time in a Capsicum annuum $\mathrm{L}$ with soft rot symptoms during the rainy season of 2008 (Gillis et al. 2017). In Costa Rica, P. carotovorum was found to cause soft rot in pineapples crops (Uribe Lorío et al. 2008).

\subsection{North America}

Pectobacterium and Dickeya spp. cause soft rot diseases on a wide range of crops and ornamental plants in North America and are responsible for significant economic losses in both field and storage crops. In particular, SRP causes soft rot and blackleg diseases in potato and have become increasingly problematic in major potato growing regions.

Over the years, the number of genera and species of soft rot bacteria has increased substantially in North America. Prior to 1990, P. atrosepticum, P. carotovorum and Dickeya spp. were the major soft rot species, although other species may not have been recognized due to a lack of advanced characterization methods.

In potato, $P$. atrosepticum has been the major causal agent of the blackleg disease in the past and is still the primary causal agent of the disease in Canada and the US. 
Other pectinolytic soft rot bacteria also detected on potato in North America include P. brasiliense, $P$. parmentieri, $P$. betavasculorum, $P$. carotovorum, and $P$. odoriferum.

$P$. brasiliense has recently been isolated in North America including both United States (Ma et al. 2007, b) and Canada (De Boer et al. 2012). Based on field trial data in Canada, local P. brasiliense isolates were less virulent on potato stems than isolates of $P$. atrosepticum and $P$. parmentieri. The low level of virulence exhibited by Canadian P. brasiliense isolates contrasts with the high virulence of the Brazilian isolates (De Boer et al. 2012). North American P. brasiliense strains form a novel clade in MLST dendrograms, separate from strains from Brazil, South Africa and other tropical regions. It is very likely that the current $P$. brasiliense group is comprised of multiple genetic groups, in which the North American group forms an individual clade, similar to strains isolated from China that form another clade. Both clades also differ from the tropical strains in that they do not produce acid from $\alpha$-methylglucoside or reducing substances from sucrose (De Boer et al. 2012), and lack of three indels identified in the tropical species or subspecies containing putative pathogenicity islands or similar gene structures (Sean Li, CFIA, Charlottetown, Canada, unpublished results).

In North America, P. parmentieri was originally isolated from decayed potato tubers in the United States (Wisconsin), and later known as potato isolates of P. wasabiae (from which P. parmentieri was derived-see Sect. 2.3) in Canada (De Boer et al. 2012). The pathogen was isolated from a number of potato stems expressing typical blackleg symptoms collected from commercial potato fields in Canada. Newly developed PCR assays confirmed that historical isolates in culture collections strongly support the hypothesis that both $P$. brasilense and P. parmentieri are not recently introduced in the potato production chain in either North America or Europe (De Boer et al. 2012). Interestingly, the presence of co-infections by multiple SRP in the same potato plant further complicates the situation (De Boer et al. 2012; Ma et al. 2007; Kim et al. 2009). From field samples in Canada, co-infection of individual potato stems by both $P$. atrosepticum and $P$. parmentieri were ascertained by multiplex PCR assays. P. carotovorum and, occasionally, P. brasiliense have also been detected in diseased potato stems along with $P$. atrosepticum or P. parmentieri (De Boer et al. 2012).

Before 2014, Dickeya spp. causing soft rot and blackleg disease in North America were rare. In 2014/2015, a dramatic increase in blackleg and non-emergence of potato occurred in the Eastern United States that caused significant losses in some potato producing areas. The pathogen was isolated and confirmed as D. dianthicola (Jiang et al. 2016). According to a recent survey, D. dianthicola has spread to all major potato-producing US states, and possibly to at least two Canadian provinces, with the epicentre being in the state of Maine (Charkowski 2018). In addition, D. dadantii and D. chrysanthemi were also found in North America. However, D. dianthicola appears, so far, to be the only Dickeya spp. causing major losses in potato in North America. D. solani was isolated from intercepted hyacinth bulbs imported from Europe and identified through comparative genomics in Canada (Li, X, Charlottetown, Canada, unpublished data).

To date, the origin of the recent outbreaks of $D$. dianthicola in North America is unknown. Whether it was caused by newly introduced, more aggressive strains or 
by existing strains that were latently present in seed tubers grown under especially conducive conditions remains a mystery. As suggested recently (Charkowski 2018), seed potatoes infected with $D$. dianthicola still remain in the seed system, and the pathway by which this pathogen enters into new seed lots in the North American seed potato system is not clear. Potato certification programs and frequent seed potato testing have played an active role in preventing spread of more virulent strains of pectinolytic soft rot bacteria such as $D$. dianthicola, $P$. brasiliense, and possibly $D$. solani.

\subsection{Concluding Remarks}

SRP species are globally widespread but the species responsible for disease on different plants may differ in different regions based on host, climate and trading policies. There are also factors, not yet (entirely) identified, that cause sudden changes in population structures in certain areas. Introduction of highly aggressive SRP strains from other crops grown in rotation with a specific crop or nearby can cause these changes. Elimination of diseased plants for planting may select for SRP strains within a plant species that are less aggressive on that species, and only cause latent infections. Subtle changes in climate or in growth of new varieties may favour specific SRP species or strains to outgrow others.

It is expected that the regional diversity of species will further increase over time. Firstly, because there is an increasing number of SRP species described. Secondly, by the introduction of 'new' strains as shown for D. solani in seed potatoes in Europe, which likely originated from hyacinths or other bulbous plants (Slawiak et al. 2009), and also for $D$. dianthicola in potato in Australia, originating from dahlia tubers (Wright et al. 2018; Tesoriero 2018).

It is expected that climate change will largely affect the degree of economic damage caused by SRP in the future. Where there are increasing periods of drought, the importance of SRP may decrease but where there is more frequent and heavy rainfall or floods, an increase in the number of disease outbreaks and disease severity may increase. Exchange of information on the presence and prevalence of specific SRP species between countries will continue to help support the management of diseases caused by SRP using appropriate, and where possible shared, detection assays to test for the presence of SRP in planting material. 


\section{References}

Abdel-Rahim AM, Adam FS (1987) Pathological and bacteriological characteristics of bacterial isolates causing soft rot of potato in the Sudan. J Univ Kuwait 14(1):127-136

Acuna B, Riffo F (1993) Blackleg survey and potential of latent infection (Erwinia spp) in certified potato seed lots in the tenth region of Chile. Agricultura Tecnica (Chile): 53(2):179-183. Instituto de Investigaciones Agropecuarias INIA Chile

Acuna I, Guttierrez M, Sandoval C, Mancilla S (2016) Pectobacterium and Dickeya situation in the potato crop in Chile. Paper presented at the Euphresco III: Assessment of Dickeya and Pectobacterium spp. on vegetables and ornamentals, Helsinki, Finland, 10-12 November 2016

Acuna I, Sandoval C, Gutiérrez M, Bermúdez A, Araya M, Mancilla S (2017) Potato seed treatment as a part of an Integrated management of blackleg and soft rot in potato. In: Paper presented at the Euphresco III: assessment of Dickeya and Pectobacterium spp. on vegetables and ornamentals, SASA, Edinburgh, Scotland, UK, 1-2 November 2017

Agha N, Fettouche F (1991) A survey of bacterial pathogens of potato in the coastal zone of Algeria. EPPO Bulleting/Bulletin OEPP 21(4):723-726

Alič Š, Pédron J, Dreo T, Van Gijsegem F (2019) Genomic characterisation of the new Dickeya fangzhongdai species regrouping plant pathogens and environmental isolates. BMC Genomics 20:34

Alippi AM, López AC (2009) First Report of Pectobacterium carotovorum subsp. carotovorum on Spathiphyllum wallisii in Argentina. Plant Dis 93(8):842

Alippi AM, Bo ED, Ronco LB, Casanova PE, Aguilar OM (1997) Tomato as a new host of Erwinia carotovora subsp. carotovora in Argentina. Plant Dis 81(2):230

Ambang Z, Mengue S, Kosma P, Asseng CC, Dooh JPN (2016) Assessing the resistance of three tomato varieties to bacterial wilt and stem rot. Am J Exp Agric 11(3):1

Anonymous (2018a) Total income from farming - estimates for Scotland 2015 to 2017. A National Statistics publication for Scotland, Edinburgh, Scotland, UK

Anonymous (2018b) Jordbruksmarkens användning, slutlig statistik. Use of agricultural land 2018. Final statistics. Sveriges officiella statistik, statistiska meddelanden JO 10 SM 1802. ISSN 1654 4102 Serie JO_-Jordbruk, skogsbruk och fiske

Anonymous (2018c) Fältbesiktningsstatistik, Potatis 2018. https://www.jordbruksverket.se/dow nload/18.73a18710165bb95e5f459dca/1536585842763/2018.pdf

Ashmawy NA, Jadalla NM, Shoeib AA, El-Bebany AF (2015) Identification and genetic characterization of Pectobacterium spp. and related Enterobacteriaceae causing potato soft rot diseases in Egypt. J Pure Appl Microbiol 9(3):1847-1858

Autrey L, Dookun A (1989) Identification and importance of soft rot erwinias infecting potato in Mauritius. In: Proceedings of the first triannual general meeting and conference, Nairobi, Kenya

Baghaee-Ravari S, Rahimian H, Shams-Bakhsh M, Lopez-Solanilla E, Antúnez-Lamas M, Rodríguez-Palenzuela P (2011) Characterization of Pectobacterium species from Iran using biochemical and molecular methods. Eur J Plant Pathol 129(3):413-425

Baghaee Ravari S, Moslemkhani K, Khodaygan P (2013) Assessment of genetic variability of prevalent pectinolytic bacteria causing potato tuber soft rot in eastern Iran. J Plant Pathol 95(1):107-113

Baghaee-Ravari S, Gerayeli N (2015) Detection of Pectobacterium carotovorum subsp. carotovorum associated with bacterial soft rot of two succulent plants in Iran using recA and pmrA genes. J Plant Pathol 143-148

Bakay V (2014) The defeat of potato by blackleg: distribution and characteristics of the pathogen population in Belarus. Agric Selection in Belarus 50:230-238 (In Russian)

Barakat F, Kararah M, Mikhail M, Fouly H (1985) Role of three species of bacteria in decaying garlic bulbs. Egypt J Phytopathol 17(2):115-129

Barannik A, Simonov R, Vasiliev D, Kabanova A, Shneider M, Ignatov A, Miroshnikov K (2018) Differentiation of potato pectolytic pathogens Pectobacterium and Dickeya ssp. by genomic fingerprinting. In: Proceedings of the international scientific conference on "Modern technologies 
and means for plant protection-a platform for innovative development of the agricultural sector in Russia", pp 25-26

Baştaş K, Hekimhan H, Maden S, Tör M (2009) First report of bacterial stalk and head rot disease caused by Pectobacterium atrosepticum on sunflower in Turkey. Plant Dis 93(12):1352-1352

Bebber DP, Holmes T, Gurr SJ (2014) The global spread of crop pests and pathogens. Glob Ecol Biogeogr 23(12):1398-1407

Borodin S, Kotlyarova I, Tereshchenko G, Pashayan N (2012) The bacterial diseases of sunflower. Oilseeds The Scientific and Technical Bulletin of the All-Russian Scientific Research Institute of Oilseeds 1:1-13 (I Russian)

Bradbury JF (1986) Guide to plant pathogenic bacteria. CAB international

CABI (2018) Dickeya zeae (bacterial stalk rot of maize) data sheet. Invasive Species Compendium. CAB International Wallingford, Oxon OX10 8DE, UK

Caldiz DO, LASA C, Bisio PE (2016) Management of grass and broadleaf weeds in processing potatoes (Solanum tuberosum L.) with clomazone, in the argentinian pampas. Am J Plant Sci 7(16):2339

Cazelles O, Schwaerzel R (1992) Enquête sur les bactérioses causées par Erwinia dans les cultures de plants de pomme de terre en Suisse. Revue Suisse Agric 24(4):215-218

Chandrashekar M, Diriwaechter G (1983) Soft rot of cyclamen in Australia caused by Erwinia carotovora ssp. carotovora. Australas Plant Pathol 12 (4):60-62

Charkowski AO (2018) The changing face of bacterial soft-rot diseases. Annu Rev Phytopathol 56:269-288

Chawki K, Quetu-Laurent A, Taghouti G, Caullireau E, Fischer-Le Saux M, Le Hingrat Y, Andrivon D, Portier P, Helias V (2018) The Pectobacterium complex: diversity and phylogeny. Phytopathology 10

Chen X, Zhang H, Chen J (2015) First report of Dickeya solani causing soft rot in imported bulbs of Hyacinthus orientalis in China. Plant Dis 99(1):155

Cherpakov V (2012) Bacterial dropsy: the affected coniferous species in Russia. Actual Problems of the Forest Complex 33:1-4 (In Russian)

Cherpakov V (2016) 2016. Taxonomic transformations of pathogens of "wet wood" . Actual Problems of the Forest Complex 46:1-6

Cherpakov V (2017) Etiology of bacterial dropsy of woody plants. News of the St. Petersburg Forestry Academy 220:125-139 (in Russian)

Choi O, Kim J (2013) Pectobacterium carotovorum subsp. brasiliense causing soft rot on paprika in Korea. J Phytopathol 161(2):125-127

Cother EJ, Gilbert RL (1990) Presence of Erwinia chrysanthemi in two major river systems and their alpine sources in australia. J Appl Bacteriol 69(5):729-738

Cother EJ, Powell V (1983) Physiological and pathological characteristics of Erwinia chrysanthemi isolates from potato tubers. J Appl Bacteriol 54(1):37-44

Czajkowski R, Grabe GJ, Van der Wolf JM (2009) Distribution of Dickeya spp. and Pectobacterium carotovorum subsp carotovorum in naturally infected seed potatoes. Eur J Plant Pathol 125(2):263-275

Czajkowski R, Pérombelon MCM, Jafra S, Lojkowska E, Potrykus M, Van der Wolf JM, Sledz W (2015) Detection, identification and differentiation of Pectobacterium and Dickeya species causing potato blackleg and tuber soft rot: a review. Ann Appl Biol 166:18-38

Dana H, Khodakaramian G, Rouhrazi K (2015) Characterization of Pectobacterium carotovorum subsp. carotovorum causing watermelon soft rot disease in Iran. J Phytopathol 163(9):703-710

Daniel J, Boher B, Kohler F (1981) Bacterial pathogens of cassava in the People's Republic of the Congo and the Central African Republic: etiology, epidemiology [Xanthomonas manihotis, Erwinia carotovora, top decline, soft rot]. Agronomie 1:751-758

De Boer SH, Li X, Ward LJ (2012) Pectobacterium spp. associated with bacterial stem rot syndrome of potato in Canada. Phytopathology 102(10):937-947

Dees MW, Lebecka R, Perminow JIS, Czajkowski R, Motyka A, Zoledowska S, Śliwka J, Lojkowska E, Brurberg MB (2017) Characterization of Dickeya and Pectobacterium strains obtained from 
diseased potato plants in different climatic conditions of Norway and Poland. Eur J Plant Pathol 148(4):839-851

Dees MW, Lysøe E, Rossmann S, Perminow J, Brurberg MB (2017b) Pectobacterium polaris sp. nov., isolated from potato (Solanum tuberosum). Int J Syst Evol Microbiol 67(12):5222-5229

Degefu Y (2015) Dickeya and Pectobacterium species: consistent threats to potato production in Europe. https://portal.mtt.fi/portal/page/portal/kasper/pelto/peruna/Potatonow/tutkimus/ Yeshitila_PotatoNow_Article.pdf

Degefu Y (2018) Extreme weather conditions and characterization of blackleg on potato during the 2018 cropping season in Finland. In: Euphresco III Dickeya and Pectobacterium workshop, Emmeloord, the Netherlands, 15-17 November 2018. Abstract

Degefu Y, Virtanen E, Vayrynen T (2009) Pre-PCR processes in the molecular detection of blackleg and soft rot Erwiniae in seed potatoes. J Phytopathol 157(6):370-378

Degefu Y, Potrykus M, Golanowska M, Virtanen E, Lojkowska E (2013) A new clade of Dickeya spp. plays a major role in potato blackleg outbreaks in North Finland. Ann Appl Biol 162(2):231-241

De Vries R, Hofland Zijlstra J, Ludeking D (2013) Beheersing van Erwinia vruchtrot in paprika. Rapport GTB-1250, PPO Bleiswijk, p 38

De Werra P, Bussereau F, Keiser A, Ziegler D (2015a) First report of potato blackleg caused by Pectobacterium carotovorum subsp. brasiliense in Switzerland. Plant Dis 99(4):551

De Werra P, Bussereau F, Kellenberger I, Dupuis B, Schaerer S, Keiser A (2015b) Potato: the Pectobacterium empire strikes back. Agrarforschung Schweiz 6:256-263

Doidge EM (1919) The role of bacteria in plant diseases. S Afr J Sci 16(1-2):65-92

Duarte V, De Boer SH, Ward LJ, de Oliveira AMR (2004) Characterization of atypical Erwinia carotovora strains causing blackleg of potato in Brazil. J Appl Microbiol 96(3):535-545

Dung J, Johnson D, Schroeder B (2012) First report of Pectobacterium wasabiae causing aerial stem rot of potato in Washington State. Plant Dis 96(12):1819-1819

Du Raan S, Coutinho TA, van der Waals JE (2016) Cardinal temperature differences, determined in vitro, between closely related species and subspecies of pectinolytic bacteria responsible for blackleg and soft rot on potatoes. Eur J Plant Pathol 144(2):361-369

El-Goorani M, Abo-El-Dahab M (1972) Root rot of Strelitzia reginae Banks caused by Erwinia carotovora (Jones) Holland. Egypt J Phytopathol 4:65-70

El Zayat M, Omar J, Taher M (1978) Studies on the blackleg disease of potato in the Libyan Jamahiriya. Libyan J Agric 7:129-136

EPPO (2018) Dickeya chrysanthemi (Erwich). EPPO Global database

Fan J, Qian G, Yang X, Gu C, Kang Y, Ma Y, Hu B, Liu F (2011) Biocontrol of bacterial soft rot of calla lily by elicitor Harpin $\mathrm{Xoo}_{\text {and }} \mathrm{N}$-acyl homoserine lactonase (AttM). World J Microb Biot 27(2):401-410

Faquihi H, Terta M, Amdan M, Achbani EH, Ennaji MM, Mhand RA (2015) Phenotypic and genotypic diversity of Pectobacterium carotovorum subsp carotovorum causing soft rot disease of potatoes in Morocco. Eur J Plant Pathol 143(4):801-811

Fassihiani A, Nedaeinia R (2008) Characterization of Iranian Pectobacterium carotovorum strains from sugar beet by phenotypic tests and whole-cell proteins profile. J Phytopathol 156(5):281-286

Faye P, Bertrand C, Pédron J, Barny M-A (2018) Draft genomes of "Pectobacterium peruviense" strains isolated from fresh water in France. Stand Genomic Sci 13(1):27

Fujimoto T, Yasuoka S, Aono Y, Nakayama T, Ohki T, Sayama M, Maoka T (2017) First report of potato blackleg caused by Pectobacterium carotovorum subsp. brasiliense in Japan. Plant Dis 101(1):241-241

Gardan L, Gouy C, Christen R, Samson R (2003) Elevation of three subspecies of Pectobacterium carotovorum to species level: Pectobacterium atrosepticum sp. nov., Pectobacterium betavasculorum sp. nov. and Pectobacterium wasabiae sp. nov. Int J Syst Evol Microbiol 53(2):381-391

Ge T, Jiang H, Hao J, Johnson S (2018) First report of Pectobacterium parmentieri causing bacterial soft rot and blackleg on potato in Maine. Plant Dis 102(2):437 
Gillis A, Santana M, Rodríguez M, Romay G (2017) First report of bell pepper soft-rot caused by Pectobacterium carotovorum subsp. brasiliense in Venezuela. Plant Dis 101(9):1671-1671

Golanowska M, Kielar J, Lojkowska E (2016) The effect of temperature on the phenotypic features and the maceration ability of Dickeya solani strains isolated in Finland, Israel and Poland. Eur J Plant Pathol 147(4):1-15

González-Rodríguez MÁ, Silva-Rojas HV, Mascorro-Gallardo JO (2005) Ensayo in vitro del péptido antimicrobiano melitina contra diferentes bacterias fitopatógenas. Revista Mexicana De Fitopatología 23(2):176-182

Gorter GJMA (1977) Index of plant pathogens and the diseases they cause in cultivated plants in South Africa, vol 392

Greiner BW (2019) Inoculation and spread of Dickeya in potatoes. Dissertation North Dakota State University

Hannukkala AO (2011) Examples of alien pathogens in Finnish potato production-their introduction, establishment and consequences. Agric Food Sci 20(1):42-61

Harju P, Kankila J (1993) Erwinia carotovora contamination of Finnish seed potatoes and the prevalence of bacterial subspecies and serogroups. Agric Sci Finland 2(4):345-352

Hugouvieux-Cotte-Pattat N, Jacot-des-Combes C, Briolay J (2019) Dickeya lacustris sp. nov., a water-living pectinolytic bacterium isolated from lakes in France. Int J Syst Evol Microbiol 69(3):721-726

Hugouvieux-Cotte-Pattat N, Brochier-Armanet C Flandrois J-P, Reverchon S (2020) Dickeya poaceiphila sp. nov., a plant-pathogenic bacterium isolated from sugar cane (Saccharum officinarum). Int J Syst Evol Microbiol (in press)

Hussain Z (1983) Identification of black leg and charcoal rot diseases of tobacco in Zimbabwe. Zimbabwe J Agric Res 21(2):179-180

Hu X, Ying F, He Y, Gao Y, Chen H, Chen J (2007) Characterization of Pectobacterium carotovorum subsp. carotovorum causing soft-rot disease on Pinellia ternata in China. Eur J Plant Pathol 120(3):305-310

Ignatov A, Karlov A, Dzahlilov F (2014) Spread of potato blackleg caused by bacteria of Dickeya genus in Russia. Plant Prot Quarantine 11:41-43 (In Russian)

Ignatov A, Egorova M, Khodykina M (2015) Spread of bacterial and phytoplasmic plant diseases in Russia. Plant Prot Quarantine 5:6-9 (In Russian)

Ignatov A, Lazarev A, Panycheva Y, Provorov N, Chebotar V (2018) Potato phytopathogens of Dickeya genus-a mini review of systematics and etiology of the diseases. Agric Biol 53:123-131 (in Russian)

Ismail ME, Abdel-Monaim MF, Mostafa YM (2012) Identification and pathogenicity of phytopathogenic bacteria associated with soft rot disease of girasole tuber. Notulae Scientia Biologicae 4(1):75-81

Jaramillo A, Huertas C, Gómez E (2017) First report of bacterial stem rot of tomatoes caused by Pectobacterium carotovorum subsp. brasiliense in Colombia. Plant Dis 101(5):830

Jiang H, Hao J, Johnson S, Brueggeman R, Secor G (2016) First report of Dickeya dianthicola causing blackleg and bacterial soft rot on potato in Maine. Plant Dis 100(11):2320-2320

Jones BL, Van der Walt L (1987) Bacterial stalk rot of sunflower in South Africa. Phytophylactica 19(1)

Kahala M, Blasco L, Joutsjoki V (2012) Molecular characterization of spoilage bacteria as a means to observe the microbiological quality of carrot. J Food Prot 75(3):523-532

Kalinichenko A, Pasichnyk L, Osypenko S, Patyka V, Usmanova H (2017) Bacterial diseases of energy plants. Ecol Chem Eng 24(2)

Karlov A, Zotov V, Pekhtereva E, Matveeva E, Dzhalilov F, Fesenko I, Karlov G (2010) Dickeya dianthicola - a novel for Russia potato bacterial pathogen. In: Proceedings of the Timiryazev Agricultural Academy in Moscow, vol 3, pp 38-48 (in Russian)

Karlov A, Vo T, Kabanova A, Pekhtereva E, Matveeva E, Norman S, Varitsev Y (2011) Diagnostics of potato bacterial pathogen Dickeya dianthicola. In: Paper presented at the proceedings of the Timiryazev Agricultural Academy in Moscow, vol 3, pp 134-141 
Khodykina M, Vo TNH, Kabanova A, Miroshnikov K, Polityko V, Pekhtereva ES, Schaad N, Ignatov A (2016) Genetic diversity in pectolityc strains of enterobacteria isolated from potato and vegetables in Russia. Potato Prot 2:3-9 (in Russian)

Kim H-S, Ma B, Perna NT, Charkowski AO (2009) Phylogeny and virulence of naturally occurring type III secretion system deficient Pectobacterium strains. Appl Environ Microbiol 75(13):45394549

Komar E, Shavel M, PresniakevichA (2013) Bacteria of the Dickeya genus-a novel causative agent of bacterial potato rot on the territory of Belarus. Actual problems of studying and preserving of phyto- and mycobiota BSU Press, pp 265-268 (in Russian)

Komar E, Shavel M, Pesnyakevich A (2014 ) The identification of gram-negative pectolytic phytopathogenic bacteria causing potato diseases in the Belarus. Bull of BSU 2:54-60 (in Russian)

Komok M (2017) Bacteriosis of soybean. How to protect the crop without reducing the yield? Grain 2:186-190 (in Russian)

Korobko A (1997) Bacterioses of sesame (Sesamum indicum L.). Mikrobiologichniĭ Zhurnal 59(2):53-61

Laing M (2009a) Soft rot of agapanthus, bulbine, clivia and wild ginger. In: Lennox C, Venter SN (eds) TA Coutinho TG. Bacterial diseases of plants in South Africa. Briza Publishers, Pretoria, South Africa, pp 163-164

Laing M (2009b) Soft rot of celery, parsley and Swiss chard. In: Lennox C, Venter SN (eds) TA Coutinho TG. Bacterial diseases of plants in South Africa. Briza Publishers, Pretoria, South Africa, pp 169-170

Laurila J, Hannukkala A, Nykyri J, Pasanen M, Helias V, Garlant L, Pirhonen M (2010) Symptoms and yield reduction caused by Dickeya spp. strains isolated from potato and river water in Finland. Eur J Plant Pathol 126(2):249-262

Lazarev A (2013) A new agent of bacteriosis of potatoes attacks the Russian fields. Prot Quarantine Pathog N Plants 6:11-15

Lazarev A, Mysnik E, Varitsev Y, Zaitsev I, Kozhemyakov A, Popov F, Volgarev S, V C (2017) Areas and zones of harmfulness of the main plant bacterioses on the territory of Russia and neighboring countries. Plant Protection News 24 (in Russian)

Lee DH, Kim JB, Lim JA, Han SW, Heu S (2014) Genetic diversity of Pectobacterium carotovorum subsp. brasiliensis isolated in Korea. Plant Pathol J 30(2):117-124

Le Hingrat Y, Hélias V, Le Roux-Nio A, Cellier G, Prior P, Rivoal C, Poliakof F, Soubelet H, Moreau M, Deveaux V, Latour X, Guaucher D, Benigni M, Martinon V (2012) Evaluation (et gestion) des risques sanitaires bactérien liés aux itinéraires culturaux de la pomme de terre et d'autres cultures spécialisées. Innov Agronomiques 25:253-267

Lemma Z, Dawit W, Negari M, Chaka A, Selvaraj T, Gebresenbet G (2014) Identification of postharvest rotting microorganisms from tomato fruits (Solanum esculentum Mill.) in Toke Kutaye District of West Shoa Zone, Ethiopia. J Stored Prod Postharvest Res 5(3):14-19

Lin B, Shen H, Zhou J, Pu X, Chen Z, Feng J (2012) First report of a soft rot of Philodendron 'Con-go' in China caused by Dickeya dieffenbachiae. Plant Dis 96(3):452-452

Lipsky A, Joshi JR, Carmi N, Yedidia I (2016) Expression levels of antimicrobial peptide tachyplesin I in transgenic Ornithogalum lines affect the resistance to Pectobacterium infection. J Biotechnol 238:22-29

Li B, Qiu W, Fang Y, Xie GL (2009) Bacterial stem rot of Oncidium orchid caused by a Dickeya sp (ex Pectobacterium chrysanthemi) in mainland China. Plant Dis 93(5):552-552

Li B, Shi Y, Ibrahim M, Liu H, Shan C, Wang Y, Kube M, Xie G-L, Sun G (2012) Genome sequence of the rice pathogen Dickeya zeae strain ZJU1202. J Bacteriol 194:4452-4453

Li XS, Yuan KX, Cullis J, Lévesque CA, Chen W, Lewis CT, De Boer SH (2015) Draft genome sequences for Canadian isolates of Pectobacterium carotovorum subsp. brasiliense with weak virulence on potato. Genome Announcements 3(2):e00240-00215

Li Z, Wang T, Luo X, Li X, Xia C, Zhao Y, Ye X, Huang Y, Gu X, Cao H, Cui Z, Fan J (2018) Biocontrol potential of Myxococcus sp. strain BS against bacterial soft rot of calla lily caused by Pectobacterium carotovorum. Biol Control 126:36-44 
Ma B, Hibbing ME, Kim H-S, Reedy RM, Yedidia I, Breuer J, Breuer J, Glasner JD, Perna NT, Kelman A, Charkowski AO (2007) Host range and molecular phylogenies of the soft rot enterobacterial genera Pectobacterium and Dickeya. Phytopathology 97(9):1150-1163

Mahmoudi E, Soleimani MJ, Taghavi M (2007) Detection of bacterial soft-rot of crown imperial caused by Pectobacterium carotovorum subsp. carotovorum using specific PCR primers. Phytopathologia Mediterranea 46(2):168-176

Matveeva E, Polityko V, Fokina V, Kornev K, Ignatov A (2008) Pathogens causing the sunflower bacteriosis in Russia and their phenotypic properties. AGRO 10:29-31 (in Russian)

Ma X, Schloop A, Swingle B, Perry KL (2018) Pectobacterium and Dickeya responsible for potato blackleg disease in New York State in 2016. Plant Dis 102(9):1834-1840

Mejía-Sánchez D, Aranda-Ocampo S, Nava-Díaz C, Teliz-Ortiz D, Livera-Muñoz M, De La TorreAlmaráz R, Ramírez-Alarcón S (2019) Pectobacterium carotovorum subsp. brasiliense causes soft rot and death of Neobuxbaumia tetetzo in Zapotitlan Salinas Valley, Puebla, Mexico. Plant Dis 103(3):398-403

Meng X, Chai A, Shi Y, Xie X, Ma Z, Li B (2017) Emergence of bacterial soft rot in cucumber caused by Pectobacterium carotovorum subsp. brasiliense in China. Plant Dis 101(2):279-287

Mériaux B (2011) Deux bactéries pour un radis. Bull Semences 221:38-40

Mikiciński A, Sobiczewski P, Sulikowska M, Puławska J, Treder J (2010) Pectolytic bacteria associated with soft rot of calla lily (Zantedeschia spp.) tubers. J Phytopathol 158(4):201-209

Moleleki LN, Onkendi EM, Mongae A, Kubheka GC (2013) Characterisation of Pectobacterium wasabiae causing blackleg and soft rot diseases in South Africa. Eur J Plant Pathol 135(2):279288

Moloto V, Goszczynska T (2007) First report of watermelon soft rot caused by Pectobacterium carotovorum subsp. carotovorum in South Africa. South Afr J Sci 2007 1-2 (Acad science south africa ass af po box 72135, lynwood ridge 0040, south africa, pp XII-XIII)

Moraes A, Souza E, Mariano R, Silva A, Lima N, Peixoto A, Gama M (2017) First report of Pectobacterium aroidearum and Pectobacterium carotovorum subsp. brasiliensis causing soft rot of Cucurbita pepo in Brazil. Plant Dis 101(2):379

Moroz S, Patika V (2011) The bacterial diseases of sunflower. Grain 1:27-33

Motyka A, Zoledowska S, Sledz W, Lojkowska E (2017) Molecular methods as tools to control plant diseases caused by Dickeya and Pectobacterium spp: a minireview. New Biotechnol 39:181-189

Muturi P, Yu J, Li J, Jiang M, Maina AN, Kariuki S, Mwaura FB, Wei H (2018) Isolation and characterization of pectolytic bacterial pathogens infecting potatoes in Nakuru Count, Kenya. J Appl Microbiol 124(6):1580-1588

Naas H, Sebaihia M, Orfei B, Rezzonico F, Buonaurio R, Moretti C (2018) Pectobacterium carotovorum subsp. brasiliense and Pectobacterium carotovorum subsp. carotovorum as causal agents of potato soft rot in Algeria. Eur J Plant Pathol 151(4):1027-1034

Nabhan S, Wydra K, Linde M, Debener T (2012b) The use of two complementary DNA assays, AFLP and MLSA, for epidemic and phylogenetic studies of pectolytic enterobacterial strains with focus on the heterogeneous species Pectobacterium carotovorum. Plant Pathol 61(3):498-508

Nabhan S, De Boer SH, Maiss E, Wydra K (2012a) Taxonomic relatedness between Pectobacterium carotovorum subsp. carotovorum, Pectobacterium carotovorum subsp. odoriferum and Pectobacterium carotovorum subsp. brasiliense subsp. nov. J Appl Microbiol 113(4):904-913

Ngadze E, Coutinho TA, Van der Waals JE (2010) First report of soft rot of potatoes caused by Dickeya dadantii in Zimbabwe. Plant Dis 94(10):1263-1263

Ngadze E, Brady CL, Coutinho TA, Van der Waals JE (2012) Pectinolytic bacteria associated with potato soft rot and blackleg in South Africa and Zimbabwe. Eur J Plant Pathol 134(3):533-549

Ngoc Ha V, Voronina M, Kabanova A, Shneider M, Korzhenkov A, Toschakov S, Miroshnikov K, Miroshnikov K, Ignatov A (2019) First report of Pectobacterium parmentieri causing stem rot disease of potato in Russia. Plant Dis 103(1):144-144

Nunes Leite L, De Haan E, Krijger M, Kastelein P, Van Der Zouwen P, Van Den Bovenkamp G, Tebaldi N, Van Der Wolf J (2014) First report of potato blackleg caused by Pectobacterium carotovorum subsp. brasiliensis in the Netherlands. New Dis Rep 29:24 
Nzabuheraheza FD, Nyiramugwera AN (2015) Anti-bacterial activity of Guizotia scabra L. and Maesa lanceolata L. extracts on Erwinia carotovora L. responsible for Irish potato soft rot in Rwanda. Afr J Food, Agric, Nutr Dev 15(4):10171-10181

Ogoshi C, Monteiro F, Becker W, Kvitschal M, Cardoza Y, Zanin J, Duarte V (2019) First report of Dickeya dadantii causing a new disease of apple trees in Brazil. New Dis Rep 39:8-8

Oliveira AM, Duarte V, Silveira JR, Moraes MG (2003) Incidence of pectolytic erwinias associated with blackleg of potato in Rio Grande do Sul. Fitopatologia Brasileira 28(1):49-53

Onkendi EM, Moleleki LN (2014) Characterization of Pectobacterium carotovorum subsp. carotovorum and brasiliense from diseased potatoes in Kenya. Eur J Plant Pathol 139(3):557-566

Oskiera M, Kałużna M, Kowalska B, Smolinska U (2017) Pectobacterium carotovorum subsp. odoriferum on cabbage and Chinese cabbage: identification, characterization and taxonomic relatedness of bacterial soft rot causal agents. J Plant Pathol 99(1):149-160

Oulghazi S, Cigna J, Lau YY, Moumni M, Chan KG, Faure D (2019a) Transfer of the waterfall source isolate Pectobacterium carotovorum M022 to Pectobacterium fontis sp. nov., a deep-branching species within the genus Pectobacterium. Int J Syst Evol Microbiol 69(2):470-475

Oulghazi S, Pédron J, Cigna J, Lau YY, Moumni M, Van Gijsegem F, Chan K-G, Faure D (2019b) Dickeya undicola sp. nov., a novel species for pectinolytic isolates from surface waters in Europe and Asia. Int J Syst Evol Microbiol 69(8):2440-2444

Oulghazi S, Moumni M, Khayi S, Robic K, Sarfraz S, Lopez-Roques C, Vandecasteele C, Faure D (2020) Diversity of Pectobacteriaceae species in potato growing regions in Northern Morocco. Microorganisms 8(6):895

Ozturk M, Aksoy H, Potrykus M, Lojkowska E (2018) Genotypic and phenotypic variability of Pectobacterium strains causing blackleg and soft rot on potato in Turkey. Eur J Plant Pathol 152(1):143-155

Panda P, Fiers M, Armstrong K, Pitman A (2012) First report of blackleg and soft rot of potato caused by Pectobacterium carotovorum subsp. brasiliensis in New Zealand. New Dis Rep 26(15):2044

Panicheva Y, Voronina M, Gresis V, Ignatov A (2017) The bacterial diseases of sugar beet in Russian Federation: distribution and harmfulness. Sugar 11:26-30 (In Russian)

Panicheva Y, Vasiliev D, Miroshnikov K, Ignatov A (2018) Species diversity of pectolytic bacteriathe pathogens of potato and sugar beet in the Russian Federation and methods for their diagnostics. Materials of the international scientific-practical conference "Modern technologies and means for plant protection - a platform for innovative development of the agricultural sector in Russia", 120-121 (In Russian)

Paradza VM, Mazarura U, Ngadze E (2016) Pathogens Causing Soft Rot and Blackleg Symptoms in Potatoes in Peri-urban Harare Area. J Agric Ecol Res Int 1-9

Parkinson N, Stead D, Bew J, Heeney J, Tsror L, Elphinstone J (2009) Dickeya species relatedness and clade structure determined by comparison of recA sequences. Int J Syst Evol Microbiol 59:2388-2393

Parkinson N, De Vos P, Pirhonen M, Elphinstone J (2014) Dickeya aquatica sp. nov., isolated from waterways. Int J Syst Evol Microbiol 64(7):2264-2266

Pasanen M, Laurila J, Brader G, Palva ET, Ahola V, Van Der Wolf J, Hannukkala A, Pirhonen M (2013) Characterisation of Pectobacterium wasabiae and Pectobacterium carotovorum subsp. carotovorum isolates from diseased potato plants in Finland. Ann Appl Biol 163(3):403-419

Pasanen M, Waleron M, Schott T, Cleenwerck I, Misztak A, Waleron K, Pritchard L, Bakr R, Degefu Y, Van der Wolf J (2020) Pectobacterium parvum sp. nov., having a Salmonella SPI-1-like Type III secretion system and low virulence. Int J Syst Evol Microbiol ijsem004057

Pauer G (1964) Erwinia carotovora f. sp. zeae, the bacterium causing stalk rot of maize in the Republic of South Africa. South Afr J Agric Sci 7:581-582

Peckham GD, Kaneshiro WS, Luu V, Berestecky JM, Alvarez AM (2010) Specificity of monoclonal antibodies to strains of Dickeya sp. that cause bacterial heart rot of pineapple. Hybridoma 29(5):383-389

Pédron J, Bertrand C, Taghouti G, Portier P, Barny M-A (2019) Pectobacterium aquaticum sp. nov., isolated from waterways. Int J Syst Evol Microbiol 69(3):745-751 
Peltzer S, Sivasithamparam K (1988) Serogroups of Erwinia carotovora associated with water soil tuber and stems of potato plants in Western Australia. New Zealand J Exp Agric 16(3):265-270

Peregrine W, Lyon N (1975) The amelioration of some potato disease problems in Malawi. Trop Agric 52(3):251-258

Perminow J, Brurberg MB, Akselsen I (2013) Potato pathogens new to Norway. In: Proceedings of the European Association for Potato Research (EAPR), Pathology Section Meeting, Jerusalem, Israel, 17-21 November 2013

Pérombelon MCM (2002) Potato diseases caused by soft rot erwinias: an overview of pathogenesis. Plant Pathol 51(1):1-12

Pérombelon MCM, Hyman LJ (1989) Survival of soft rot coliforms Erwinia carotovora ssp carotovora and Erwinia carotovora ssp atroseptica in soil in Scotland UK. J Appl Bacteriol 66(2):95-106

Pérombelon MC, Kelman A (1980) Ecology of the soft rot erwinias. Annu Rev Phytopathol 18(1):361-387

Pérombelon M, Kelman A (1987) Blackleg and other potato diseases caused by soft rot Erwinias: proposal for revision of terminology. Plant Dis 71(3):283-285

Persson P (1988) Blackleg and stem rot of potatoes in Sweden. Acta Agriculturae Scandinavica 38(2):177-182

Persson P, Rölin A (2014) Stjälkbakterios—kartläggning av nya skadegörare i Sverige Slutrapport till Stiftelsen lantbruksforskning, projekt H1142175

Pitman AR, Wright PJ, Galbraith MD, Harrow SA (2008) Biochemical and genetic diversity of pectolytic enterobacteria causing soft rot disease of potatoes in New Zealand. Australas Plant Pathol 37(6):559-568

Pitman A, Harrow S, Visnovsky S (2010) Genetic characterisation of Pectobacterium wasabiae causing soft rot disease of potato in New Zealand. Eur J Plant Pathol 126(3):423-435

Podkina D (2005) Bacterial diseases of soybean. In: Soybean, biology, and technology of cultivation. All-Russian Research Institute of Oilseeds. Krasnodar, Russian Federation, pp 70-73 (in Russian)

Portier P, Pédron J, Taghouti G, Fischer-Le Saux M, Caullireau E, Bertrand C, Laurent A, Chawki K, Oulgazi S, Moumni M, Andrivon D, Dutrieux C, Faure D, Hélias V, Barny M-A (2019) Elevation of Pectobacterium carotovorum subsp. odoriferum to species level as Pectobacterium odoriferum sp. nov., proposal of Pectobacterium brasiliense sp. nov. and Pectobacterium actinidiae sp. nov., emended description of Pectobacterium carotovorum and description of Pectobacterium versatile sp. nov., isolated from streams and symptoms on diverse plants. Int J Syst Evol Microbiol 69(10):3214-3223

Potrykus M, Sledz W, Golanowska M, Slawiak M, Binek A, Motyka A, Zoledowska S, Czajkowski R, Lojkowska E (2014) Simultaneous detection of major blackleg and soft rot bacterial pathogens in potato by multiplex polymerase chain reaction. Ann Appl Biol 165(3):474-487

Potrykus M, Golanowska M, Sledz W, Zoledowska S, Motyka A, Kolodziejska A, Butrymowicz J, Lojkowska E (2016) Biodiversity of Dickeya spp. isolated from potato plants and water sources in temperate climate. Plant Dis 100(2):408-417

Prins H, Breukers A (2008) In de puree? De gevolgen van aantasting door Erwinia voor de aardappelsector in kaart gebracht. LEI Internal Report. Den Haag, The Netherlands

Qian GL, Fan JQ, Chen DF, Kang YJ, Han B, Hu BS, Liu FQ (2010) Reducing Pectobacterium virulence by expression of an $N$-acyl homoserine lactonase gene $\mathrm{P}_{\text {lpp-aiiA in Lysobacter enzymogenes }}$ strain OH11. Biol Control 52(1):17-23

Ravari SB, Shams-Bakhsh M, Rahimian H, Safaei N (2010) Phenotypic and genotypic diversity of pectolytic erwinias isolated from ornamental hosts in some northern parts of Iran. Iran J Plant Pathol 46(3):61-64

Ribas ADR (2007) Detecção de Pectobacterium carotovorum subsp. brasiliensis em plantas de batata através de PCR com oligonucleotídeos iniciadores a partir das sequiências dos genes pnl e rdg. Universidade federal do Rio Grande do Sul, Rio Grande, Brazil 
Rommel CC, Duarte V (2002) Identificação e incidência de pectobactérias em tubérculos de batata importados da Argentina e Chile. Salão de Iniciação Científica (14: 2002: Porto Alegre) Livro de resumos Porto Alegre: UFRGS, 2002

Rosenzweig N, Steere L, Kirk W, Mambetova S, Long C, Schafer R, Dangi S, Byrne J (2016) First report of Dickeya dianthicola and Pectobacterium wasabiae causing aerial stem rot of potato in Michigan, USA. New Dis Rep 33(10):2044

Rossmann S, Dees MW, Perminow J, Meadow R, Brurberg MB (2018) Soft rot Enterobacteriaceae are carried by a large range of insect species in potato fields. Appl Environ Microbiol 84(12)

Rungnapha K, Yu S, Xie G (2008) Bacterial stem rot of poinsettia caused by a Dickeya sp (Pectobacterium chrysanthemi) in China. Plant Dis 92(7):1135

Saleh O (1991) Studies of bacterial soft rot of onion bulbs. Ann Agric Sci 36(1):241-253

Sarfraz S, Riaz K, Oulghazi S, Cigna J, Sahi ST, Khan SH, Faure D (2018) Pectobacterium punjabense sp. nov., isolated from blackleg symptoms of potato plants in Pakistan. Int J Syst Evol Microbiol 68(11):3551-3556

Sarfraz S, Sahi ST, Oulghazi S, Riaz K, Rajput NA, Atiq M, Tufail MR, Hameed A, Faure D (2019) Species diversity of Dickeya and Pectobacterium causing blackleg disease in potato fields in Pakistan. Plant Dis PDIS-08

Sarris P, Trantas E, Pagoulatou M, Stavrou D, Ververidis F, Goumas D (2011) First report of potato blackleg caused by biovar 3 Dickeya sp. (Pectobacterium chrysanthemi) in Greece. New Dis Rep 24:21

Serfontein S, Logan C, Swanepoel A, Boelema B, Theron D (1991) A potato wilt disease in South Africa caused by Erwinia carotovora subspecies carotovora and E. chrysanthemi. Plant Pathol 40(3):382-386

Sheluho V, Sidorov V (2009) Diagnosis and distribution of birch bacteriosis in the Bryansk region. Forest J 6:53-58 (In Russian)

She X, He Z, Tang Y, Du Z, Lan G (2013) First report of potato blackleg disease caused by Pectobacterium atrosepticum in Guangdong China. Plant Dis 97(12):1652-1652

Sinha S, Prasad M (1977) Bacterial stalk rot of maize, its symptoms and host-range. Zentralblatt Für Bakteriologie, Parasitenkunde, Infektionskrankheiten Und Hygiene Zweite Naturwissenschaftliche Abteilung: Allgemeine, Landwirtschaftliche Und Technische Mikrobiologie 132(1):81-88

Slawiak M, van Beckhoven JRCM, Speksnijder AGCL, Czajkowski R, Grabe G, van der Wolf JM (2009a) Biochemical and genetical analysis reveal a new clade of biovar 3 Dickeya spp. strains isolated from potato in Europe. Eur J Plant Pathol 125(2):245-261

Sławiak M, Łojkowska E, Van Der Wolf JM (2009b) First report of bacterial soft rot on potato caused by Dickeya sp. (syn. Erwinia chrysanthemi) in Poland. Plant Pathol 58(4):794-794

Sławiak M, Van Doorn R, Szemes M, Speksnijder AGCL, Waleron M, Van Der Wolf JM, Łojkowska E, Schoen CD (2013) Multiplex detection and identification of bacterial pathogens causing potato blackleg and soft rot in Europe, using padlock probes. Ann Appl Biol 163(3):378-393

Sledz W, Jafra S, Waleron M, Lojkowska E (2000) Genetic diversity of Erwinia carotovora strains isolated from infected plants grown in Poland. EPPO Bull 30(3-4):403-407

Slootweg C, Dijkema M, Van der Wolf J, Meekes E, Westerhof J (2015) Bacterieziekten in de bloemisterij (Bacterial diseases in ornamental crops). Wageningen UR, Business Unit Bloembollen, Boomkwekerij en Fruit, Wageningen. Internal Report Wageningen UR, p 59

Snijder RC, Cho HR, Hendriks MMWB, Lindhout P, van Tuyl JM (2004) Genetic variation in Zantedeschia spp. (Araceae) for resistance to soft rot caused by Erwinia carotovora subsp. carotovora. Euphytica 135(1):119-128

Snir P, Luria G (2009) Choosing Zantedeschia aethiopica cultivars: "Iseraeli Calla", "Coloumn de la Peache"and "Innocence". Flowering Newsletter 6:46-49

Soleimani-Delfan A, Etemadifar Z, Emtiazi G, Bouzari M (2015) Isolation of Dickeya dadantii strains from potato disease and biocontrol by their bacteriophages. Braz J Microbiol 46(3):791797 
Soto JA, Puglia MC (2002) Podredumbre radical bacteriana del alcaucil en Mendoza (Argentina)Artichoke bacterial in soft-rot Mendoza (Argentina). Revista de la Facultad de Ciencias Agrarias $34(2)$

Stevenson W, Loria R, Franc G, Weingartner D (2001) Compendium of potato diseases. The American Phytopathological Society Press, St. Paul, MN, USA, p 144

Stirling AM (2002) Erwinia chrysanthemi, the cause of soft rot in ginger (Zingiber officinale) in Australia. Australas Plant Pathol 31(4):419-420

Suárez MB, Feria F, Martín-Robles M, del Rey F, Palomo J (2017) Pectobacterium parmentieri causing soft rot on potato tubers in Southern Europe. Plant Dis 101(6):1029-1029

Swart V, Swart W (2000) The current status of research on diseases of Opuntia ficus-indica in South Africa. In: IV international congress on cactus pear and cochineal 581, pp 239-245

Tanton T, Abington J (1979) The effect of different cultural practices upon the major diseases of dark fire-cured tobacco in Malawi. PANS 25(2):158-162

Tatarintsev A (2014) Ecological-coenotic characteristics of the bacterial dropsy infection rate in birch forests in the southern part of Middle Siberia (Krasnoyarsk group of areas). Contemp Problems Ecol 7(2):221-227

Terblanche J (2009) Hallow stalk and barn rot of tobacco. In: Lennox C, Venter SN (eds) TA Coutinho TG. Bacterial diseases of plants in South Africa. Briza Publishers, Pretoria, South Africa, pp 179-180

Tesoriero L (2018) Review bacterial blackleg disease and R\&D gaps with a focus on the potato industry. Final Report. Hort Innovations, Sydney, Australia

Tian Y, Zhao Y, Xie H, Wang X, Fan J, Hu B (2015) First report of bacterial soft rot of seleng wormwood caused by Pectobacterium carotovorum subsp. carotovorum in China. Plant Dis 99(8): 1175

Tian Y, Zhao Y, Yuan X, Yi J, Fan J, Xu Z, Hu B, De Boer SH, Li X (2016) Dickeya fangzhongdai sp. nov., a plant-pathogenic bacterium isolated from pear trees (Pyrus pyrifolia). Int J Syst Evol Microbiol 66(8):2831-2835

Toth IK, van der Wolf JM, Saddler G, Lojkowska E, Helias V, Pirhonen M, Tsror L, Elphinstone JG (2011) Dickeya species: an emerging problem for potato production in Europe. Plant Pathol 60(3):385-399

Tsror L, Aharon M, Erlich O (1999) Survey of bacterial and fungal seedborne diseases in imported and domestic potato seed tubers. Phytoparasitica 27(3):215-226

Tsror L, Erlich O, Lebiush S, Hazanovsky M, Zig U, Slawiak M, Grabe G, van der Wolf JM, van de Haar JJ (2009) Assessment of recent outbreaks of Dickeya sp (syn. Erwinia chrysanthemi) slow wilt in potato crops in Israel. Eur J Plant Pathol 123(3):311-320

Tsror L, Erlich O, Lebiush S, Van der Wolf J, Czajkowski R, Mozes G, Sikharulidze Z, Ben Daniel B (2011) First report of potato blackleg caused by a biovar 3 Dickeya sp. in Georgia. New Dis Rep 23:1

Tsror L, Ben-Daniel B, Chalupowicz L, van der Wolf J, Lebiush S, Erlich O, Dror O, Barel V, Nijhuis E, Manulis-Sasson S (2013) Characterization of Dickeya strains isolated from potato grown under hot-climate conditions (Plant Pathology). Plant Pathol 62(5):1097-1105

Tsror L, Lebiush S, Erlich O, Galilov I, Chalupowicz L, Reuven M, Dror O, Manulis-Sasson S (2019) First report of latent infection of Malva nicaeensis caused by Pectobacterium carotovorum subsp. brasiliense in Israel. New Dis Rep 39:4

Tsror L, Erlich O, Mordechai-Lebiush S, Galilov I, Hazanovsky M, Chalupowicz L, Reuven M, Dror O, Manulis S (2020) First report of Pectobacterium parmentieri one of the causal agents of potato blackleg and tuber soft rot diseases in Israel. Plant Dis. https://doi.org/10.1094/PDIS-0220-0226-PDN

Tzerkovnaia V (2011) The relationships of the pathogens causing onion fusariosis and bacterioses. Plant Prot Quarantine 11:45-46 (in Russian)

Uribe Lorío L, Arauz LF, Mata M, Meneses G, Castro Barquero L (2008) Efecto del vermicompostaje sobre las poblaciones de Colletotrichum acutatum y Pectobacterium carotovorum presentes en residuos de plantas. Agronomía Costarricense 33(1) 
Ustun N, Arslan N (2016) Bacterial stem rot of globe artichoke (Cynara cardunculus var. scolymus) caused by Pectobacterium carotovorum subsp. carotovorum in Turkey. J Plant Pathol 98:91-96

Van der Merwe JJ, Coutinho TA, Korsten L, van der Waals JE (2010) Pectobacterium carotovorum subsp. brasiliensis causing blackleg on potatoes in South Africa. Eur J Plant Pathol 126(2):175185

Van der Wolf JM, Nijhuis EH, Kowalewska MJ, Saddler GS, Parkinson N, Elphinstone JG, Pritchard L, Toth IK, Lojkowska E, Potrykus M, Waleron M, de Vos P, Cleenwerck I, Pirhonen M, Garlant L, Hélias V, Pothier JF, Pflüger V, Duffy B, Tsror L, Manulis S (2014) Dickeya solani sp. nov., a pectinolytic plant pathogenic bacterium isolated from potato (Solanum tuberosum). Int J Syst Evol Microbiol 64(3):768-774

Van der Wolf JM, de Haan EG, Kastelein P, Krijger M, de Haas BH, Velvis H, Mendes O, KoomanGersmann M, van der Zouwen PS (2017) Virulence of Pectobacterium carotovorum subsp. brasiliense on potato compared with that of other Pectobacterium and Dickeya species under climatic conditions prevailing in the Netherlands. Plant Pathol 66(4):571-583

Van Doorn J, Vreeburg PJM, Leeuwen PJV, Dees RHL (2011) The presence and survival of soft rot (Erwinia) in flower bulb production systems. Acta Horticulturae 886:365-379

Vinogradova S, Kyrova E, Ignatov A (2014) Whole genome sequencing of phytopathogenic bacteria. Potato Prot 2:15-17 (In Russian)

Voronina M, Kabanova A, Shneider M, Korzhenkov A, Toschakov S, Miroshnikov K, Miroshnikov K, Ignatov A (2019) First report of Pectobacterium carotovorum subsp. brasiliense causing blackleg and stem rot disease of potato in Russia. Plant Dis 103(2):364-364

Waleron M, Waleron K, Lojkowska E (2002) Genotypic characterisation of the Erwinia genus by PCR-RFLP analysis of rpoS gene. Plant Prot Sci 38(Special Issue 2):288-290

Waleron M, Waleron K, Lojkowska E (2013) Occurrence of Pectobacterium wasabiae in potato field samples. Eur J Plant Pathol 137(1):149-158

Waleron M, Waleron K, Lojkowska E (2014) Characterization of Pectobacterium carotovorum subsp. odoriferum causing soft rot of stored vegetables. Eur J Plant Pathol 139(3):457-469

Waleron M, Waleron K, Lojkowska E (2015) First report of Pectobacterium carotovorum subsp. brasiliense causing soft rot on potato and other vegetables in Poland. Plant Dis 99(9):1271-1271

Waleron M, Misztak A, Waleron M, Franczuk M, Wielgomas B, Waleron K (2018) Transfer of Pectobacterium carotovorum subsp. carotovorum strains isolated from potatoes grown at high altitudes to Pectobacterium peruviense sp. nov. Syst Appl Microbiol 41(2):85-93

Waleron M, Misztak A, Waleron M, Franczuk M, Jońca J, Wielgomas B, Mikiciński A, Popović T, Waleron K (2019a) Pectobacterium zantedeschiae sp. nov. a new species of a soft rot pathogen isolated from Calla lily (Zantedeschia spp.). Syst Appl Microbiol 42(3):275-283

Waleron M, Misztak A, Waleron M, Jonca J, Furmaniak M, Waleron K (2019b) Pectobacterium polonicum sp. nov. isolated from vegetable fields. International J Syst Evol Microbiol 69(6):17511759

Wang J, Wang L, Wang F, Cao G, Rao GP, Cheng C, Zhang M (2016) First report of bacterial soft rot on Anubias barteri var. nana caused by Dickeya dadantii in China. Plant Dis 100(2):519

Wang J, Wang Y, Dai P, Chen D, Zhao T, Li X, Huang Q (2017) First report of tobacco bacterial leaf blight caused by Pectobacterium carotovorum subsp. brasiliense in China. Plant Dis 101(5):830 830

Wang X, He S-W, Guo H-B, Han J-G, Thin KK, Gao J-S, Yao Wang Y and Zhang X-X (2020) Dickeya oryzae sp. nov., isolated from the roots of rice. Int J Syst Evol Microbiol ijsem004265

Wright PJ (1998) A soft rot of calla (Zantedeschia spp.) caused by Erwinia carotovora subspecies carotovora. New Zealand J Crop Hortic Sci 26(4):331-334

Wright D, Bwye A, Banovic M, Baulch J, Wang C, Hair S, Hammond N, Coutts B, Kehoe M (2018) First report of Dickeya dianthicola in potatoes in Australia. Plant Dis 102(10):2029-2029

Xie H, Li X, Ma Y, Tian Y (2018) First report of Pectobacterium aroidearum causing soft rot of chinese cabbage in China. Plant Dis 102(3):674

Yishay M, Burdman S, Valverde A, Luzzatto T, Ophir R, Yedidia I (2008) Differential pathogenicity and genetic diversity among Pectobacterium carotovorum ssp. carotovorum isolates from 
monocot and dicot hosts support early genomic divergence within this taxon. Environ Microbiol 10(10):2746-2759

Yuan F, Qu Shu P, Cui Chong S, Cao Ming Q, Ma Rong C (2004) A new strain of Erwinia carotovora subsp. carotovora isolated from soft-rotted Chinese cabbage. Weishengwu Xuebao 44(2):136-140

Zaitsev I, Varitsev Y, Lazarev A, Galushka P, Varitseva G (2016 ) Monitoring of latent forms of distribution of pathogens causing blackleg and ring rot of potato in Russian Federation. Agricultural Sciences: Scientific Priorities of Scientists Perm, Russian Federation, pp 38-55 (in Russian)

Zayed A, Maayouf M (1989) First record of soft rot on imported potato varieties in Great Libyan Jamahiriya. Arab J Plant Prot 7(2):172-173

Zhang J, Lin B, Shen H, Pu X, Chen Z, Feng J (2012) First report of bacterial soft rot of potato caused by Pectobacterium carotovorum subsp. carotovorum in Guangdong province of China. Plant Dis 96(12): 1819

Zhang JX, Lin BR, Shen HF, Pu XM, Wang ZW, Zeng DQ, Huang N (2013) First report of bacterial soft rot on tagetes patula caused by Dickeya dieffenbachiae in China. Plant Dis 97(2):282

Zhang J, Shen H, Pu X, Lin B, Hu J (2014) Identification of Dickeya zeae as a causal agent of bacterial soft rot in banana in China. Plant Dis 98(4):436-442

Zhao Y, Li P, Huang K, Wang Y, Hu H, Sun Y (2013) Control of postharvest soft rot caused by Erwinia carotovora of vegetables by a strain of Bacillus amyloliquefaciens and its potential modes of action. World J Microbiol Biotechnol 29(3):411-420

Zhao Y, Dou J, Geng G, Tian Y, Fan J, Li X, Hu B (2018) First report of Pectobacterium carotovorum subsp. brasiliense causing blackleg and stem rot on potato in China. Plant Dis 102(8):1653

Zoledowska S, Motyka A, Zukowska D, Sledz W, Lojkowska E (2018) Population structure and biodiversity of Pectobacterium parmentieri isolated from potato fields in temperate climate. Plant Dis 102(1):154-164 